\title{
Atatürkçü Düşünce Sistemi: Atatürkçülük (Kemalizm)
}

\section{Mehmet KAYIRAN* Mustafa Yahya METINTAŞ ${ }^{* * *}$}

$\ddot{O} z e t$

Dünyadaki bağımsızlık savaşlarının önderi Mustafa Kemal; milli, üniter yeni bir Türk devleti kurmuş, bu devlete çağdaşlaşmanın yol ve yöntemini de göstermiştir. Türk inkılâbı ile hayata geçirilmiş olan bu model, "Atatürkçülük" olarak adlandırılmıştır. Türkiye Cumhuriyeti'ni sonsuza kadar yaşatmanın bir garantisi olan "Atatürkçülük - Kemalizm" birbirini izleyen, birlikte bir bütün oluşturan çok yönlü bir düşünce sistemidir. Atatürkçülük, "totaliter - dogmatik”, değil; "demokratik ve pragmatik” bir ilkeler bütünüdür. Çünkü Atatürk'ün Türk milletine bıraktığ yegâne fikri - manevi mirası "akıl ve bilimdir".

Araştırmamızın amacı "Türk Devrimi”ne yön veren "Atatürkçü Düşünce Sistemi”ne dün olduğu gibi, bugün de Türkiye’nin günümüzde ve gelecekte karşılaşabileceği sorunlarının çözümünde kullanılabilecek etkili bir model olduğunu vurgulamaktır. Bu incelemede, "Türk Inkılâbı"nın düşünsel temellerini oluşturan Atatürkçülük; Mustafa Kemal'in eylem ve söylemleri esas alınarak bir bütünlük içinde değerlendirilmiştir. Sistemi

Anahtar Kelimeler: Kemalizm, Atatürkçülük, Atatürk Yolu, Atatürkçü Düşünce Abstract
Kemalist Thought System: Kemalism
Mustafa Kemal, the leader of the world wars of independence, has set up a new
unitary Turkish state and pointed out the way and method of the modernization to
the state. This model, which has been implemented by the Turkish Revolution, is

\footnotetext{
* Eskişehir Osmangazi Üniversitesi, Fen Edebiyat Fakültesi, Tarih Bölümü Öğretim Üyesi.

** Eskişehir Osmangazi Üniversitesi, Fen Edebiyat Fakültesi, Tarih Bölümü Öğretim Üyesi.
} 
named as "Kemalism". Kemalism, which is a guarantee of the Republic of Turkey to keep alive forever, is a consecutive multi-directional thought system that makes up a whole. Kemalism is not a "totalitarian - dogmatic" but is a "democratic and pragmatic" set of principles. Because the only idea left from-the spiritual heritage of-Ataturk to the Turkish nation is the "reason and science".

The aim of our research is to emphasize that, as was in the past, "Kemalist Thought System", which has guided the "Turkish Revolution", is still an effective method that can be used to solve the problems that will be encountered currently and in the future. In this investigation, Kemalism, which constitute the ideational basis of the "Turkish Revolution", was evaluated in a holistic approach based on the actions and statements of Mustafa Kemal.

Key Words: Kemalism, The Way of Ataturk, Kemalist Thought Systems

\section{Giriş}

“'Atatürkçü Düşünce Sistemi, Atatürkçülük, Kemalizm, Atatürk Yolu’” gibi terimler; Türk İnkılâbı'nın ideolojisini oluşturan eş anlamlı deyimlerdir. Atatürk'ün önderliğinde gerçekleştirilen Türk Devrimi tarihi ve sosyolojik gelişmelerin bir sonucudur. Devrime temel teşkil eden prensipler Mustafa Kemal'e göre, yaşanmış hayattan alınmış ve Türk ulusunun iradesi ile oluşturulmuş sosyal bir gerçekliktir. Atatürk'ün yaşamı boyunca düşünüp yazdığ 1 ve uygulamalarıyla hayata geçirdiği prensipler kümesi, "Atatürk İlkeleri'” olarak adlandırılmıştır.

Atatürk'ün düşünce sisteminin oluşmasına neden olan olaylar, düşünürler, yazarlar ve kitaplar incelendiğinde; O’nun yalnızca bir olayın bir düşüncenin, akımın izleyicisi olmadığı, çağının değişik görüş ve düşüncelerini kendine özgü bir senteze ulaştırmış olduğu görülür. Hiç kuşkusuz her insan gibi Mustafa Kemal de; içinde bulunduğu toplumsal, kültürel çevrenin ve yaşadığı döneme damgasını vuran büyük olaylar ile siyasal akımların etkisinde kalmıştır. Ancak, Atatürk'ü diğer insanlardan ayıran bir büyük özellik O'nu ve büyük eserini Türk ulusuna ve "mazlum milletlere' kazandırmıştır. Bu özellik; Atatürk'ün döneminin düşüncelerini, okuduklarını, gördüklerini, deneyimlerini topluca değerlendirerek "yeni bir bileşkeye belirli bir düşün düzeyine" ulaştırabilme ayrıcalığına sahip olmasının bir sonucudur. "Büyük" diye nitelendirilen kişileri diğer insanlardan ayıran özelliklerin başında yer alan bu yetenek, "Atatürkçü düşünce sisteminin oluşmasında da belirleyici öğe olmuştur.",

\footnotetext{
${ }^{1}$ Şerafettin Turan, Atatürk'ün Düşünce Yapısını Etkileyen Olaylar, Düşünürler, Kitaplar, Ankara, 1982, s. 1-51; Mehmet Kayıran, “Atatürkçü Düşünce Sisteminin Oluşmasına Neden
} 
Mustafa Kemal, Osmanlı Devleti'nin bir liman kenti olan Selanik'te 1881 'de doğmuştu. Bu kent, Avrupalı büyük devletlerin ticaret, finans kontrolü ve jandarma gözetimi altına konmuş olan bir bölgesiydi. O'nun 1938 yılına kadar olan yaşamı, çökme ve dağılma aşamalarını geçirmekte olan, geleneksek ilkelerini yitirmiş bulunan bir "Saltanat-Hilafet rejiminden bir Ulus-Cumhuriyet Devleti rejimine geçişin dramı içinde geçmiştir.,'2

Atatürk'e göre, “insanları istediği gibi kullanan kuvvet, düşünceler ve bu düşünceleri sezinleyen kimselerdir."3 Mustafa Kemal, kendisine yön veren düşüncenin kaynağını şöyle özetlemiştir ${ }^{4}$ :

“'Bizim yolumuzu çizen içinde yaşadığımız yurt, bağrından çıktığımız Türk milleti ve bir de milletler tarihinin bin bir facia ve izdırap kaydeden yapraklarından çıkardığımız neticelerdir.',

Türk halkını akıl ve bilimsel gelişmeler tarafından belirlenmiş ahlaki bir yaşayışa kavuşturmayı benimsemiş olan Atatürk'ün fikir ve eylemleri bir bütündür. Atatürkçülük olarak da adlandırılan “ Altı Atatürk İlkesi”'nin temel amacı; Türkiye Cumhuriyeti'ni çağdaş bir devlet olarak sonsuza kadar yaşatmaktır. Devletin ve toplumun ana hedeflerini sağlam bir rehber niteliğinde dengede tutan bu fikirler kümesi; ilk kez 1931 yılında "Cumhuriyet Halk Fırkası"'nın Programında": "Cumhuriyetçilik, Milliyetçilik, Halkçılık, Devletçilik, Lâiklik ve İnkılâpçılık” olarak sıralanmıştır. Değişen zaman ve koşullara göre geliştirilen bu temel ilkeler, 5 Şubat 1937'de Türkiye Cumhuriyeti'nin ilk Anayasası'nda yer almıştır. 1924 Anayasası'nın 2. Maddesi şöyledir": "Türkiye Devleti Cumhuriyetçi, Milliyetçi, Halkçı, Devletçi, Laik ve İnkılâpçıdır. Resmi dili Türkçedir, Makarrı Ankara şehridir."

\section{Cumhuriyetçilik}

Atatürk, "Millî Mücadele"nin başından hayata gözlerini kapayıncaya kadar; "halkın içinde kalmak ve her şeyi halk ile beraber yapmak" kararını vermişti ${ }^{7}$. Millî birlik ve beraberliği sağlamak için harekete geçen Mustafa Kemal Paşa, “İngiltere'nin koruyuculuğu”, “Amerika'nın güdümü” ve

Olan Etkenler ve Bu Düşünce Sistemi'nin Geliştirilmesi', Anadolu Üniversitesi FenEdebiyat Fakültesi Dergisi, C.2 (1990), S.2, s.189.

${ }^{2}$ Niyazi Berkes, “Yüz Y1l İçinde Atatürk', Atatürk ve Devrimler, İstanbul, 1982, s.74.

${ }^{3}$ Şerafettin Turan, a.g.e. , s.1.

${ }^{4}$ Utkan Kocatürk, Atatürk'ün Fikir ve Düsünceleri, Ankara, 2005, s.3.

${ }^{5}$ Cumhuriyet Halk Firkası Programı, T.B.M.M. Matbaas1, Ankara, 1931, s. 4- 5.

${ }^{6}$ Suna Kili - A. Şeref Gözübüyük, Türk Anayasa Metinleri: Senedi İttifaktan Günümüze, Ankara, 1985, s. 111.

${ }^{7}$ Cemal Kutay, Kurtulușun ve Cumhuriyet'in Manevi Mimarları, Ankara, 1973, s. 200. 
"bölgesel kurtuluş" çarelerine yönelik kurtuluş önerilerinin yerine "ciddi ve hakiki karar"ın ne olduğunu şöyle açıklamıştır": " Baylar, bu durum karşısında bir tek karar vardı. O da ulus egemenliğine dayanan, tam bağımsız yeni bir Türk devleti kurmak." ölüm!’

Gerçek kurtuluşu isteyenlerin parolası da saptanmıştı: "Ya istiklal ya

Atatürk uygulamayı bir takım evrelere ayırarak, olay ve olgulardan yararlanarak, ilk kararını verdiği çizgiden ve yöneldiği amaçtan hiç ayrılmadan Türk Devrimi'ni gerçekleştirmiştir. O’nun önderliğinde 23 Nisan 1920'de Ankara'da ulusal istek ve irade doğrultusunda yeni bir "Türk Devleti" kurulmuş, "Milletin istiklâlini yine milletin azim ve kararı kurtaracaktır" düsturu hayata geçirilmiş ve ülke işgalden kurtarılmıştır. "Hilafet-i Seniye"nin kişisel hükümetinden halkın kolektif ve demokratik hükümetine" geçme mücadelesi de kesintisiz bir biçimde sürdürülmüştür. Siyasal, sosyo - ekonomik, kültürel bağımsızlaşma ve bütünleşme sağlandıktan sonra; 20 Ocak 1921 tarihli Anayasa'nın devlet biçimini saptayan maddelerinin değiştirilmesi, 29 Ekim 1923'de kabul edilerek "Cumhuriyet" ilân edilmiştir'. Egemenliğin kayıtsız şartsız millete ait olduğu ve TBMM'nin milletin tek ve gerçek sahibi olduğunun kabul edildiği, saltanatın da kaldırılmasından sonraki yönetim biçimi, geniş anlamıyla bir cumhuriyetten başka bir şey değildi. Eksik olan, dar anlamıyla cumhuriyet, yani seçimle gelmiş bir devlet başkanlığı makamıydı. Bu açıdan 29 Ekim 1923 tarihli Anayasa değişikliği ile var olan bir durum açılığa kavuşturuldu ${ }^{10}$.

Atatürk'e göre bir milletin dayandığı esaslar": "İstiklâl-i tam" ve "Bilakayt ve şart hâkimiyet-i milliye"den ibarettir. Türkiye'deki demokratik gelişmelerin kilometre $\operatorname{taşlar1}^{12}$ : Sened-i İttifak, Tanzimat reformları, 1. Meşrutiyet, 2. Meşrutiyet ve en nihayet "Kemalist ve post Kemalist Cumhuriyet"tir. Türk demokrasisi benzer deneyim ve geleneklere sahip ülkeler arasında en başarılı olanıdır. Tarihsel süreç içinde doğup gelişen millî egemenlik ilkesini binlerce yıllık Türk tarihinde ilk kez uygulamaya sokan

\footnotetext{
${ }^{8}$ Mustafa Kemal Atatürk, Nutuk - Söylev, C. 1, Ankara, 1986, s. 17-19.

9 Mehmet Kayıran, "Atatürk, Demokrasi ve Cumhuriyetçilik", ESOGU Osmangazi Haber, Eskişehir, Kasım 2003, s. 5.

${ }^{10}$ Bülent Tanör, Osmanl1 - Türk Anayasal Gelișmeleri, İstanbul, 1992, s. 229.

${ }^{11}$ Afet İnan, Vatandaș İçin Medeni Bilgiler, 1. Kitap, İstanbul, 1933, s. 20.

12 Bernard Lewis, Demokrasi'nin Türkiye Serüveni, Çev.: Hamdi Aydoğan- Esra Ermert, 2003, s. 51.
} 
devlet adamı da Mustafa Kemal'dir. Atatürk'ün cumhuriyetçilik ilkesi ise ulusal egemenlik ilkesinin zorunlu bir sonucudur ${ }^{13}$.

Cumhuriyet sözcüğünün Fransızca karşıllı̆̆ "Republique", İngilizce karşı1lığ 1 ise "Republic" olup, Latince "Res Publica" kavramından türetilmiştir. "Res Publica"; kamu malı, devletin kamuya ait olması anlamını ifade eder ${ }^{14}$.

Dilimize Arapça'dan giren "Cumhuriyet" kelimesinin kökeni ise "Cumhur"dur. Arapça "Cumhur" sözcüğü, "halk, ahali, kalabalık" anlamına gelir. Cumhur toplu bir halde bulunan kavmi veya milleti, belli bir sinif insanı ifade eder. "Cumhuriyye - Cumhurî" ise "millete, halka mahsus" demektir. ${ }^{15}$

Görüldüğü gibi biri batı, diğeri doğu kökenli olan bu kelimelerin etimolojik karşılıkları aynı anlamı ifade etmektedir. Yani cumhuriyet, egemenliğin halka ait olduğu, hükümet biçimi demektir. Böyle bir hükümette halkı idare edenler, kamunun menfaatini daima göz önünde bulundurmak ve kendi menfaatlerinin de halk menfaatleriyle beraber olduğunu unutmamak zorundadırlar. Cumhuriyet, halkın üstünde hiçbir otorite ve yetkili makam tanımamakta ve devlet gücü doğrudan doğruya halkı oluşturan bireylerin elinde bulunmaktadır. Demokratik cumhuriyetle yönetilen devletlerde halk egemenliği devleti oluşturan tüm bireylerin tek tek iradelerinin bir araya gelmesinden oluşmuştur ${ }^{16}$. Cumhuriyet idaresi, çoğunluğun iradesi doğrultusunda bir yönetimi öngörmekle birlikte, azınlığın da temel hak ve özgürlüklerini tanımak, dokunmamak ve korumak zorundadır.

Her devlet için üç zorunlu unsurun varlığ sınırları olan bir vatan (ülke), onun üzerinde yaşayan bir insan topluluğu (millet - halk) ve ortak bazı özelliklere sahip insanların kendi içinden çıkardıkları güç yani egemenliktir. Bu üç öğeden birinin yokluğu devletin de ortadan kalkmasına neden olur. Egemenlik, mutlaka toplumun içinden çıkan bir güçtür. Egemenliğin kullanılış şekilleri de bize devletlerin idari sistemlerini gösterir. En genel anlamda insanlık tarihi boyunca üç yönetim biçimi görülmüştür. Egemenliğin aynı soydan gelen bir kişi tarafından kullanılmasına "monarşi”, belli bir grubun elinde olmasına "oligarşi", toplumun bütününe ait olmasına ise "demokrasi" adı verilmektedir. Her demokrasi "Cumhuriyet" olmadığı gibi, her cumhuriyet de demokrasi

\footnotetext{
${ }^{13}$ Ahmet Mumcu, Atatürkçülükte Temel İlkeler, İstanbul, 1981, s. 97.

${ }^{14}$ Ana Britannica, Cilt: 6, s. 251.

${ }_{15}$ Ferit Develioğlu, Osmanlıca - Türkçe Ansiklopedik Lügat, Ankara, 1993, s. 145.

${ }^{16}$ Anıl Çeçen, Atatürk ve Cumhuriyet, Ankara, 1981, s. 8-9.
} 
değildir. Bu nedenle cumhuriyet ve demokrasi birbirinin aynı olmamakla birlikte, demokrasinin bir uygulama biçimi olarak cumhuriyet ortaya çıkmıştır ${ }^{17}$.

Cumhuriyet yönetiminin tarihini, İlkçağ'daki eski Yunan'a kadar uzatanlar vardır... Yunan site devletleri ve Orta Çă̆ İtalyan kent cumhuriyetleri olsa olsa "oligarşik cumhuriyetlerdir" ${ }^{18}$. "Demokrasi ve Cumhuriyet" yönetimleri monarşik rejime karş1 bir tepki olarak doğmuşlardır. Belli bir grubun yönetimde söz sahibi olabildikleri bir yönetim şeklinin adı cumhuriyet olsa bile bu tarz idareleri "oligarşı" olarak adlandırmak daha doğru olur. Çünkü insanlık tarihinde demokrasinin gelişmesi: (1) Yönetenlerin yetkilerini yönetilenler lehine sınırlandırmak; (11) Mümkün olduğu kadar daha fazla kişinin oy kullanabilmesini sağlayarak yönetime katılanların sayısını azamî ölçüde arttırmak; ${ }^{19}$ (111) Güçler ayrılığını hayata geçirmek ve yargıyı bağımsız hale getirmek yönünde olmuştur. "Cumhuriyet ve demokrasi arasındaki ilişki genel anlamda bir biçim ve öz ilişkisidir".

Atatürk'e göre, “demokrasi prensibinin en asrî ve mantıki tatbikini temin eden hükümet şekli cumhuriyettir ${ }^{20}$. Ancak demokrasi ile cumhuriyet her zaman iç içe geçmiş kavramlar değildir. Bu anlamda ne her cumhuriyet bir demokrasidir ne de her demokrasi bir cumhuriyettir. Tarihte öyle cumhuriyetler vardır ki, bunlarda millet, egemenlik hakkını doğrudan ve sınırsız olarak kullanacak kişileri seçmektedir. Bu seçim sırasında ulusal egemenlikten söz edilse de seçim bitince, egemenlik hemen tümüyle devredilmiş olur, bir temsil söz konusu sayılmaz. Bu tür cumhuriyetlerde ulusal egemenlik belli grup ya da kişilerin çıkarları için kullanılan bir araçtan başka bir şey değildir. Buna karş1lık kuramsal olarak egemenliğin tam anlamıyla ulusa ait olmadığı, devlet başkanının seçimle değil; kalıtım yoluyla geldiği rejimler vardır. Bu tür rejimlerin bazılarında vatandaşların özgürlükleri, güvenlikleri sağlanmıştır. Gerçi devlet başkanını seçemezler ama kendi adlarına yasaları yapıp uygulayacak yöneticileri başa getirebilirler. Bu tür monarşik devletler Avrupa'da halâ bulunmaktadır. (İngiltere, İsveç, Norveç, Belçika, Danimarka, Hollanda, İspanya, Lüksemburg monarşik demokrasi ile yönetilen ülkelerdir) Ancak demokrasi ile cumhuriyet'in özdeşleştiği rejimler en ülküsel yapıyı gösterenlerdir. Ulusal egemenliğin tümüyle ve kısıntısız yaşandığı bir demokratik ortam

\footnotetext{
${ }^{17}$ Ahmet Mumcu, Atatürk İlkeleri ve İnkılap Tarihi II, Eskişehir, 1994, s. 114-127.

${ }^{18}$ Toktamış Ateş, Cumhuriyet, Ankara, 1986, s. 39-40.

${ }^{19}$ Anıl Çeçen, a.g.e., s. 30-36.

${ }^{20}$ Afet İnan, Medeni Bilgiler ve Mustafa Kemal Atatürk'ün El Yazıları, 2. Baskı, Ankara, 1988, s. 32.
} 
içinde en mükemmel gelişme sağlanabilir. ${ }^{21}$ Atatürk'e göre demokrasi, "bugün modern devlet yapısının genel bir simgesi"dir ve "artık demokrasi fikri daima yükselen bir denizi andırmaktadır" ${ }^{22}$.

Cumhuriyet, demokrasinin bütün anlamıyla ideali, bütün bireylerin ve milletin, aynı zamanda yöneten durumunda bulunmasını, hiç değilse devletin son idaresini, yalnızca milletin ifade etmesini ve açılamasını ister. Yazık ki milletleri nüfus artışı, düşünsel eğitim düzeyleri bu idealin uygulanmasında; idealden büsbütün yoksun kalmayı gerektirecek hazırlıksızlıklardan kaçınmayı gerektirir. Bundan dolayıdır ki demokrasi prensibinin en modern ve mantıklı uygulamasını sağlayan hükümet biçimi cumhuriyettir. ${ }^{23}$

"Ulusal Egemenlik ve Cumhuriyet": Türk toplumu özde olmasa bile şekil bakımından1876'dan beri anayasalı, parlamentolu düzenle tanışmıştır. Özellikle 21 Ağustos 1909'dan itibaren parlamenter sistemle bu geleneği yerleştirme ve kalıcı demokratik sistem kurma yolunda çabalar harcamıştır. "Yasal olmasa bile", fiilen Mondros Mütarekesi'nden sonra varlığını yitiren Osmanlı Devleti'nin yerine "bir avuç Türk'ün barındığı ata yurdunda" ulus egemenliğine dayanan "yeni bir Türk Devleti" kurulurken, bu devletin temel yapısını belirleyecek hukuki düzenlemeler de yapılmıştır ${ }^{24}$. "Gerçek anlamda milli egemenlik ilkesi" ise Türk tarihine ve Türk devlet yapısına ilk defa Atatürk ile birlikte girmiş ve yerleşmiştir. Hâkimiyet sözcüğü ile eş anlamlı olarak kullanılan "egemenlik", hükmeden, buyuran, söz geçirebilen, istediğini yaptırabilen ${ }^{25}$ anlamlarına gelmektedir. Egemen bir güç kendi yetki alanında herhangi bir üst otoriteye bağlı ve bağımlı olmayan güç demektir. Cumhuriyet ile yönetilen demokratik devletlerde yönetilenlerin yönetenleri seçme ve denetleme hakları hiçbir biçimde sınırlandırılamaz.

Atatürk; "Cumhuriyetçilik, Milliyetçilik ve Laiklik" ilkelerini partiler üstü tutmuş ve tartışma konusu yapılmamasını önermiştir. "Atatürkçü Cumhuriyetçilik" ilkesi ile ilgili şu devrimler gerçekleştirilmiştir: (1) TBMM açılmış; (11) 1921 Anayasası kabul edilmiş; (111) Saltanat'a son verilmiş; (1v) Cumhuriyet ilan edilmiş; (v) 1924 tarihli Türkiye Cumhuriyeti'nin ilk Anayasa'sı hazırlanmış ve uygulanmış; (vı) Demokrasinin vazgeçilmez unsuru olan çok partili yaşama geçiş tecrübeleri yapılmıştır.

\footnotetext{
${ }^{21}$ Ahmet Mumcu, a.g.e. 1981, s. $112-113$.

${ }^{22}$ Afet İnan, a.g.e., s. 29.

${ }^{23}$ Reşat Kaynar - Necdet Sakaoğlu, Atatürk Düşüncesi: Sorular ve Konferanslar, İstanbul, 1999, s. 19.

24 İhsan Güneş, Meșrutiyetten Cumhuriyet'e Türkiye'de Hükümetler: Programları ve Meclisteki Yankıları (1908 - 1923), İstanbul, 2012, s. XII - XIII.

${ }^{25}$ Ömer Demir - Mustafa Acar, Sosyal Bilimler Sözlüğ̈̈, Ankara, 1997, s. 72.
} 
Atatürk'e göre, demokrasinin en gelişmiş devlet yönetim biçimi cumhuriyet'tir. (I) "Bolşevizm"; (II) "İhtilalci Siyasi Sendikalizm"; (III) "Menfaatlerin Temsili" nazariyeleri çağın demokrasiye aykırı akımlarıdır $^{26}$. Mustafa Kemal, demokrasinin belirgin özelliklerini "siyasidir", "fikridir", "ferdidir" ve "en nihayet müsavatperverdir" biçiminde özetlemiştir. O'na göre, “demokrasinin bu ferdi ve müsavatperver vasıflarından, umumî ve müsavî rey prensibi çıkar" ${ }^{27}$. Anlaşılacağ 1 üzere Cumhuriyetçilik ulusun tüm bireylerinin eşit bir biçimde yönetime katılmalarını öngörmüştür. $\mathrm{Bu}$ yönüyle Cumhuriyetçilik; demokratik, özgürlükçü, eşitlikçi, çoğulcu bir ilkedir. Milletin günü ve geleceğini kayıtsı şartsı kendisinin belirlemesi "Atatürkçü Cumhuriyetçilik" ilkesinin esasını oluşturmuştur.

\section{Cumhuriyetçilik ilkesinin belirgin özellikleri ve hedeflerini ise şöyle özetleyebiliriz:}

1. Millet iradesini esas alan bir ilkedir.

2. Cumhuriyetçilik, demokrasi bilincini yerleştirmeyi ve geliştirmeyi amaç edinmiştir.

3. Cumhuriyetçilik, Türkiye'nin bağımsızlığının sonsuza kadar sürmesini sağlayacak bir garanti belgesidir.

4. Ulusal birlikve bütünlüğün güvencesi Cumhuriyetçilik ilkesidir.

5. Türkiye'nin yönetimini toplumsal gruplartn, ailelerin eline bırakılmamasinı öngören bu ilke çağdaşlaşmanın da lokomotifidir.

6. Cumhuriyetçilik; "yurtta barış, dünya'da barış” özlemini hayata geçirmeyi amaç edinen ilkedir.

\section{Milliyetçilik (Ulusçuluk)}

Yeni Türk Devleti'nin nitelikleri, Atatürk'ün devlet anlayışına hâkim olan "millî devlet, tam bağımsızlık ve millî egemenlik" ilkeleri ile O'nun bütün atılımlarına ve inkılâplarına yön vermiş olan çağdaşlaşma (modernleşme) hedefinden kaynaklanmıştır ${ }^{28}$.

Dünya ve Türkiye'deki demokratik gelişmeleri içselleştiren Atatürk ${ }^{29}$, 19 Mayıs 1919'da Samsun'a çıktığı zaman; "Hâkimiyet-i millîyeye müstenit

\footnotetext{
${ }^{26}$ Afet İnan, a.g.e., s. 45-49.

${ }^{27}$ A.g.e., s. $29-30$.

28 Ergun Özbudun, "Atatürk ve Devlet Hayatı", Atatürk İlkeleri ve İnkılap Tarihi II: Atatürkçülük, Ankara 1986, s. 33-97.

${ }^{29}$ Bernard Lewis, a.g.e., s. 50-52.
} 
yeni bir Türk Devleti kurmak" ülküsünü ve çağdaş bir millet olma bilincini halkımıza kazandırmaya başlamıştır. Amasya Genelgesi ile "Milletin istiklâlini yine milletin azim ve kararı kurtaracaktır" diyen Mustafa Kemal ${ }^{30}$, Erzurum ve Sivas Kongreleri'nde ise "kuvay-1 milliyeyi amil ve millî iradeyi hâkim kılmanın esas olduğu" düşüncesini milletin temsilcilerine de onaylatmış ve genelleştirmiştir ${ }^{31}$. Milletin temsilcilerinin kendi yurdunun sınırlarını belirlediği "Misak-1 Millı̂”nin ilkeleri de Erzurum ve Sivas Kongresi kararlarına uygun olarak Mustafa Kemal tarafından hazırlanmıştır. İstanbul'daki Meclis-i Mebusan'ın çalışmasına işgalci devletler tarafından izin verilmeyince; Mustafa Kemal, olağanüstü yetkilere sahip TBMM'nin toplanmasını sağlamıştır. 1. TBMM'nin Ankara'da açılması ve sonrası yeni bir Türk Devleti'nin tarih sahnesine çıkışının öyküsüdür.

Yeni Türk Devleti'nin temellerini oluşturan millî egemenlik ve millî devlet ilkeleri, "Türk milliyetçiliğinin zorunlu bir sonucudur"32. Mustafa Kemal'in Millî Mücadele'nin önderliğini yapmaya başlamasıyla Türk Milleti kendini ifade etti ve Türk millî cereyanı kendi şuur ve vicdanını buldu ${ }^{33}$. Millî Mücadele'nin dayandığı en sağlam düşünüş ve mantık Atatürk'e göre şu idi ${ }^{34}$ :

"Temel Illke, Türk ulusunun onurlu bir ulus olarak yaşamasıdır. Bu ancak tam bağımsı olmakla sağlanabilir... Yabancı bir devletin koruyuculuğunu ve kollayıcıllı̆ını istemek insanlık niteliklerinden yoksunluğu, güçsüzlüğ̈̈ ve beceriksizlĭgi açı̆̆a vurmaktan başka bir şey değildir... Oysa Türkün onuru, kendine güveni ve yetenekleri çok yüksek ve büyüktür. Böyle bir ulus tutsak yaşamaktansa yok olsun, daha iyidir.

Öyleyse, ya istiklâl ya ölüm! Işste gerçek kurtuluşu isteyenlerin parolası bu olacaktır."

Atatürk'ün bu sözlerinden anlaşılacağı üzere, "Atatürkçü Milliyetçilik" ilkesi, Türk İnkılâbının gerekçesini ve hedefini tayin etmekte ve Türklük bilincinin özünü oluşturmaktadır. Milliyetçilik ve Türkçülük düşüncesini bilimsel bir biçimde analiz eden Ziya Gökalp'a göre ${ }^{35}$ :

\footnotetext{
${ }^{30}$ Hamza Eroğlu, Atatürk ve Millî Egemenlik, Ankara, 1998, s. 20.

Mehmet Kayıran, "Ulusal Egemenliğe Doğru Erzurum ve Sivas Kongrelerinin Toplanması", Anadolu Üniversitesi Eğitim Fakültesi Dergisi, Cilt 3, Sayı: 1, (1990), s. 171183.

${ }^{32}$ Ergun Özbudun, a.g.m., s. 46.

${ }^{33}$ Kaplan, Mehmet - Enginün, İnci - Zeynep Kermen vd., “Ahmet Ağaoğlu, Milliyetçilik

Cereyanının Esasları”, Atatürk Devri Fikir Hayatı, C. I, Ankara, 1981, s. 122.

${ }^{34}$ Gazi Mustafa Kemal (Atatürk), Nutuk (Söylev), C. I, Ankara 1986, s. 19.

${ }^{35}$ Ziya Gökalp, Türkçülüğün Esasları, İstanbul, 1955, s. 118-119.
} 
“Osmanlı Devleti'nde Anadolu Inkılâbı'na kadar, Türk kelimesi ăgza alınmazdl. Hiç kimse ben Türk'üm demeye cesaret edemezdi... Gazi Mustafa Kemal Paşa hazretlerinin irşad ve rehberliğiyle Türkiye düşman istilasinda kurtarllırken, diğer taraftan da devletimize, milletimize, lisanımıza hakiki adlarin verdi ve siyasetimizi mutlaklyetin ve unsurlar siyasetinin son izlerinden bile kurtardl..."

Yalnızca milletine güvenen ve Türk İnkılâbı'nı milletinin eseri olduğunu pekçok konuşmasında vurgulayan Mustafa Kemal ${ }^{36}$, milletine olan güvenini de şöyle ifade etmiştir ${ }^{37}$ :

“Ben 1919 senesi Mayısı içinde Samsun'a çıktığım gün elimde hiçbir kuvvet yoktu. Yalnız büyük Türk milletinin asaletinden doğan ve benim vicdanımı dolduran yüksek ve manevi bir kuvvet vardı. İste ben bu ulusal kuvvete, bu Türk Milleti'ne güvenerek işe başladım."

Kuşkusuz Atatürk'ün vicdanını dolduran yüksek manevi miras, O'nun düşünce ve eylemlerine yön veren yurtseverliğidir, milliyetçiliğidir. O'nun karakteri, "hürriyet ve bağımsızlıktır." Mustafa Kemal'e göre ${ }^{38}$ :

“...Bir millete şerefin, haysiyetin, namusun ve insanliğln varliğl ve kalıcilı̆̆ mutlaka o milletin hürriyet ve bağımsızlı̆̆ına sahip olmasıyla mümkündür. ...Ben yaşayabilmek için mutlaka bağımsız bir milletin evladı kalmalıyım."

"Büyük şeyleri yalnız büyük milletler yapar",39 diyen Mustafa Kemal'in Milliyetçilik anlayışı, Ziya Gökalp'in 1915'de yazmış olduğu "Millet" adlı şiirinde de ifade edilmiş olan ${ }^{40}$ tarih bilincinin bir sonucudur:

"Sorma bana oymağımı boyumu,

Beş bin yıldır millet gibi yaşarım,

Deme bana, Oğuz, Kayı, Osmanl,,

Türküm bu ad her ünvandan üstündür.”

Avrupa'da yavaş yavaş uyanmaya başlayan milliyetçilik fikirleri "milli devlete" geçişi hızlandırdı. "Rönesans ve Reformun etkileri, Coğrafi keşifler", Fransa'nın bütünleşmesi, Almanya'nın parçalanması, Otuz Yı1 Savaşları ve nihayet 1648 'de Westphalia Barışı'nın imzalanması

\footnotetext{
${ }^{36}$ Enver Ziya Karal, Atatürk’ten Düșünceler, İstanbul, 1986, s. 167-185.

${ }^{37}$ A.g.e., s. 182.

${ }^{38}$ Fethi Naci [Kalpakçığlu], 100 Soruda Atatürk'ün Temel Görüșleri, İstanbul, 1968, s. 12.

${ }^{39}$ Afet İnan, Vatandaș İçin Medeni Bilgiler, I. Kitap, İstanbul, 1933, s. 7.

${ }^{40}$ Turhan Feyzioğlu, Atatürk ve Millîyetçilik, Ankara, 1996, s. 241.
} 
“Aydınlanma Çağı”nın etkileri ile birlikte Avrupa'nın çehresini değiştirdi. Özellikle Westphalia Barışı'nın imzalanması sonrasında 300 kadar Alman devleti hemen hemen bağımsız siyasi birimler oldular. Avrupa'nın diğer devletleri mutlakıyetçi monarşiler altında birleşirken Almanya feodal bir karışıklık içine girdi. $\mathrm{Bu}$ durum Fransa'nın dünya üstünlüğünü eline geçirmesinde etken oldu ${ }^{41}$.

Modern anlamda Milliyetçilik akımı 1789 Fransız İhtilâli ve onu izleyen Napolyon'un istilalarının da etkisiyle hürriyet, eşitlik, adalet gibi ilkeler Avrupa'ya yayılmış ve millî devletlerin sayıları artmıştır. Sonuçta hanedanlıklara dayalı imparatorluklar çökmüştür ${ }^{42}$. Osmanlı İmparatorluğunu kurtarmaya yönelik "Osmanlıcılık", "İslâmcılık" gibi siyasi ideolojiler devleti yaşatmakta yetersiz kalmış ve "Türkçülük" siyasi düşüncesi temeli üzerine millî bir Türk devleti kurulmuştur. Atatürk'e göre, her millete uyabilecek bir tanım şöyle yapılabilir ${ }^{43}$ :

a. Zengin bir hattra mirasina sahip bulunan;

b. Beraber yaşamak hususunda müşterek arzu ve muvafakatte samimi olan;

c. Ve sahip olunan mirasin muhafazasina beraber devam hususunda iradeleri müşterek olan insanların birleşmesinden vücuda gelen cemiyete millet denir.

Mustafa Kemal'e göre ${ }^{44}$ : "Millet, dil, kültür ve mefkûre birliği ile birbirine bağlı vatandaşların teşkil ettiği bir siyasi ve içtimai heyettir." Atatürk'ün Türk milleti tanımı ise gerçek anlamda "Atatürkçü Milliyetçilik" anlayışının bir özeti gibidir ve şöyledir" : "Türkiye Cumhuriyeti'ni kuran Türkiye halkına Türk Milleti denir.”

Atatürk'e göre, Türk milletinin oluşumunda mevcut olan şartların tümü birden diğer milletlerde yok gibidir. Mustafa Kemal, Türk milletinin teşekkülünde mevcut olan bu öğeleri şöyle sıralandırmıştır ${ }^{46}$ :

a. Siyasal varlıkta birlik.

b. Dil birliği.

\footnotetext{
${ }^{41}$ Charles Seignobos, Avrupa Milletleri'nin Mukayeseli Tarihi, Çev.: Semih Tiryakioğlu, İstanbul, 1960, s. 227 - 234; Anadolu Üniversitesi Açıöğretim Fakültesi, Avrupa Tarihi, (Editör: Mehmet Kayıran), Eskişehir, 1991, s. 94-98 ve 109.

${ }^{42}$ Yusuf Sarınay, Atatürk'ün Millet ve Millîyetçilik Anlayıș1, İstanbul, 1996, s. 17-18.

${ }^{43}$ Afet İnan, Vatandaș İcin Medeni Bilgiler, 1. Kitap, s. 23-24.

${ }^{44}$ Ayn1 yer, s. 7.

45 Ayn1 yer, s. 7.

${ }_{46}$ Ayn1 yer, s. 13-14.
} 


\section{c. Yurt birliği. \\ d. Irk ve menşe birliği. \\ e. Tarihi karabet. \\ f. Ahlakî karabet.}

“Atatürkçü Milliyetçilik İlkesi”, 13-14 Mayıs 1931'de kabul edilen “Cumhuriyet Halk Fırkası Programı”nda şöyle tanımlanmıştır ${ }^{47}$ :

"Fırka, terakkî ve inkişâf yolunda ve beynelmilel temas ve münasebetlerde bütün muasır milletlere muvazi ve onlarla bir ahenkte yürümekle beraber Türk içtimaî heyetinin hususi seciyelerini ve başlı başına müstakil hüviyetini mahfuz tutmayı esas sayar."

Ulusal varlığımıza düşman olanlarla dost olmayalım böylelerine karşı bir Türk ozanının dediği gibi ${ }^{48}$ "Türküm ve düşmanım sana kalsam da bir kişi” diyelim uyarısını yapan Mustafa Kemal, en büyük Türk milliyetçisidir. Enver Ziya Karal'a göre, Türk milliyetçiliği bir doktrin değildir. Emperyalizm, faşizm ve rrkçılıkla da bir ilgisi yoktur. Türk milliyetçiliği "hümaniteryandır". "Atatürkçü Milliyetçilik" ya da "Türk Milliyetçiliğì", ulusal sınırlarımız dışında yaşayan Türklerle geçmişte aynı tarihe ve bu tarihin meydana getirdiği ortak kültüre sahip olmamız nedeniyle kültürel açıdan ilgilidir ${ }^{49}$.

Peyami Safa'ya göre ${ }^{50}$, “Türk İnkılâbı ve Türk milliyetçiliği kendinden evvelki bazı dağınık tekâmülü ve tavazzuhu olsa bile, bir ideoloji hüviyetiyle hiçbir peşin düşünceye mal edilemez. Türk İnkılâbı'nın bir kitabı varsa canlı bir tarihtir ve hayatın ta kendisidir... Osmanlı olmayı bile reddeden Türk milliyetçiliği yüzde yüz Türk'tür ve onu kendi kendisi olmaktan men edebilecek her düşünceye, her harekete karşı millî bir mukavemetle dimdik tutan şey de budur."

Atatürk'ün milliyetçiliği, Türk milletini muasır medeniyet seviyesine yükseltme projesidir ${ }^{51}$. Ümmet esasına dayalı bir devlet - toplum yapısından kurtuluş mücadelesi Türk İnkılâbı'nın en önemli amaçlarından biridir.

\footnotetext{
${ }^{47}$ Cumhuriyet Halk Firkas1 Programı, Ankara, 1931, s. 5.

48 Nihat Sami Özerdim, Atatürkçünün El Kitabı: Doğumu'nun 100. Y1lında Atatürk'e Armağan, Ankara, 1981, s. 125-126.

${ }^{49}$ Enver Ziya Karal, “Atatürk ve Türk Devriminin Özellikleri”, Atatürkçü Düșünce, Ankara, 1992, s. 411.

${ }^{50}$ Peyami Safa, Türk İnkılâbı'na Bakıșlar, Ankara, 1981, s. 179-186.

${ }^{51}$ Nuray Karaca, "Cumhuriyet'in İnşasında Millîyetçilik", Türk Yurdu, Cilt: 32, Sayı: 295, (Mart 2012), s. 400.
} 
Milliyetçilik ilkesini hayata geçirmeye yönelik başlıca devrimler şunlardır: (1) Cumhuriyetçilik ve Laiklik İlkeleri ile ilgili tüm devrimler; (11) Türk Tarih Kurumu'nun açılmasi; (111) Türk Dil Kurumu'nun açılması; (1v) Kültürel alandaki diğer ink1lâplar.

Atatürk milliyetçiliği, "ümmetten millet bilincine geçişin sonucudur." "Ümmet olarak çöküş millet olarak doğuştur" ${ }^{52}$. Bu nedenle de milliyetçilik, Türkiye halkının çimentosudur, ülkenin ve millî birliğin sembolüdür.

Hayatını Türk ulusunu yüceltmek için harcayan Atatürk, hiçbir kişisel ve maddi çıkar peşinde koşmamıştır. Milletin efendisi Türk köylüsüne örnek oluştursun düşüncesiyle "on beş seneden beri sebatlı ve bilgili çalışmalarının eseri olan" çiftliklerini Haziran 1937'de Türk milletine bağışlamıştır. Milyonlarca lira değerindeki bu bağışını Türk köylüsüne hizmet amacıyla yaptığ 1 küçük bir görev olarak adlandıran Atatürk: "Ben icap ettiği zaman en büyük hediyem olmak üzere Türk milletine canımı vereceğim" demiştir ${ }^{53}$.

Milliyetçilik ilkesi diğer Atatürk ilkeleri ile birlikte 5 Şubat 1937'de kabul edilen bir kanunla Anayasa'ya girmiştir ${ }^{54}$. Değişiklikle ilgili tasarı üzerine söz alan İçişleri Bakanı Şükrü Kaya, o dönemin hükümetinin Milliyetçilik anlayışının, "Türkçü", "millîci", "medeniyetçi", "barışçı", "insancıl", "eşitlikçi”", niteliklere sahip olduğunu şöyle vurgulamıştır

"Türk Devleti behemehâl Türkçü ve millîci olmak lâzımdır. Türk milletini insanllk içinde medeniyete yarar, sulha hadim, mümtaz bir kitle yapmak için evvel emirde Türk milletini layı olduğu medeniyet seviyesine çıkarmak lazımdır. Bu itibarla millîci olmak bizim şiarımızdır. Fakat millîci şiarımız dar ve inhisarcı değildir. Bizim milletimiz medeni dünya içinde onun esaslı bir unsuru olarak insanlığın yükselmesine, bütün dünyanın refah ve saadet içinde yaşamasına matuf bir Milliyetçiliktir."

Atatürk'ün Onuncu Cumhuriyet Bayramı münasebetiyle Ankara'da yapmış olduğu konuşma; O'nun Milliyetçilik anlayışının bir özeti niteliğindedir. Mustafa Kemal, "Onuncu Y1l Söylevi"nde milleti ile birlikte yaptıklarını, yapmak zorunda olduklarını ve Türk milletinin niteliklerini şöyle ilân etmiştir ${ }^{56}$ :

\footnotetext{
${ }^{52}$ Özcan Yeniçeri, "İmparatorluktan Cumhuriyete Türk Millîyetçiliğinin Tarihi Evrimi”, Türk Yurdu, C. 13 (Eylül 2011), S. 289, s. 169-175.

${ }^{53}$ İzzet Öztoprak, Atatürk Orman Ciftliğinin Tarihi, Ankara, 2006, s. 114.

${ }^{54}$ Suna Kili - Şeref Gözübüyük, a.g.e., s. 111.

${ }^{55}$ TBMM Zabit Ceridesi, Devre V, Cilt 16 (5 Şubat 1937), s. 60.

${ }^{56}$ Atatürk'ün Söylev ve Demeçleri (1906-1938), C. II, Ankara, 1959, s. 275-276.
} 
“...Az zamanda çok ve büyük işler yaptık. Bu işlerin en büyüğü, temeli Türk kahramanlı̆ğ ve yüksek Türk kültürü olan Türkiye Cumhuriyetidir.

Fakat yaptıklarımızı asla kâfi görmeyiz. Çünkü daha çok ve daha büyük işler yapmak mecburiyetinde ve azmindeyiz. Yurdumuzu dünyanın en mâmur ve en medeni memleketleri seviyesine çıkaracağız. Milletimizi en geniş refah vasıta ve kaynaklarına sahip kılacă̆ız. Millî kültürümüzü muasır medeniyet seviyesinin üzerine çıkaracă̆ız.

... Daha az zamanda, daha büyük işler başaracağız. Bunda da muvaffak olacağımıza şüphem yoktur. Çünkü Türk milleti zekidir. Çünkü Türk milleti millì birlik ve beraberlikle güçlükleri yenmesini bilmiştir. Ve çünkü Türk milletinin yürümekte olduğu terakki ve medeniyet yolunda elinde ve kafasında tuttuğu meşale, müspet ilimdir.

...Türk milletinin büyük millet olduğunu bütün medeni âlem, az zamanda, bir kere daha tanıyacaktır.

... Asla şüphem yoktur ki, Türklügün unutulmuş büyük medeni vasfi ve büyük medeni kabiliyeti, bundan sonraki inkişafi ile atinin yüksek medeniyet ufkunda yeni bir güneş gibi doğacaktır...

Ne mutlu Türküm diyene!"

Anlaşılacağ1 üzere Atatürk, "Gençliğe Hitabesi" ve "Onuncu Y11 Söylevi” ile: Türk milletinin bağımsızlığını, özgürlüğünü koruma ve yükseltme görevini Türk gençlerine ve Türk milletine vermiştir. Bu kutsal görev: "Türk istiklâlini ve Türk Cumhuriyetini ilelebet muhafaza ve müdafaa etmektir" Atatürk'e göre, ${ }^{57}$ Türk ulusunun varlığının ve geleceğinin biricik temeli budur. "Atatürkçü Milliyetçilik" anlayışı da bundan başka bir şey değildir.

1924 Anayasası'na göre ${ }^{58}$ : “Türkiye'de din ve 1 rk ayırt edilmeksizin vatandaşlık bakımından herkese Türk denir". Atatürk'ün "Türkiye Cumhuriyetini kuran Türkiye halkına Türk milleti denir" tanımlamas1 ve "Ne mutlu Türk olana" değil; "Ne mutlu Türküm diyene!" sözü Atatürk milliyetçiliğinin bölgesel, 1rksal ve dinsel bir milliyetçilik olmadığını gösterir. Zira Türkiye sınırları içinde Türk dili ile konuşan, Türk kültürü ile yetişen, başta siyasal varlıkta birlik ilkesini benimseyen her birey Türk'tür. $\mathrm{Bu}$ nedenle milli iradenin temsilcisi TBMM Mustafa Kemal'e soy adını soyadı olarak vermiştir.

\footnotetext{
${ }^{57}$ Gazi Mustafa Kemal, Nutuk - Söylev: (1920 - 1927), C. II, s. 1190-1191.

${ }^{58} 1924$ Anayasas1, Madde: 88, Suna Kili - Şeref Gözübüyük, a.g.e, s. 128.
} 
“Atatürkçü Milliyetçilik”; Türkiye Cumhuriyeti halkını eşit kabul eder. Mustafa Kemal, fahri hemşerisi bulunduğu Diyarbakır'da çıkan “Diyarbekir" gazetesi sahibine 4 Ekim 1932'de Dolmabahçe Sarayı'nda şu demeci vermiştir" : "Diyarbakırl, Vanlı, Erzurumlu, İstanbullu, Trakyalı ve Makedonyalı hep bir ırkın evlatları, aynı cevherin evlatlarıyı."

\section{Atatürkçü Milliyetçilik ilkesinin belirgin nitelikleri ve hedefleri ise şöyle özetlenebilir:}

1. Milliyetçilik ilkesi millî birlik ve bütünlüğün güvencesidir.

2. Millî devlet ve millî egemenlik ilkeleri Atatürk milliyetçiliğinin zorunlu sonuçlarıdır.

3. Atatürkçü Milliyetçilik ilkesi dinsel, mezhepsel ${ }^{60}$, etnik, bölgesel vb. her türlü ayrımcılı̆̆a karşıdır.

4. Milliyetçilik Türk kültürünü yükseltmeyi, Türk milletini çağdaş medeniyet seviyesinin üzerine çıkarmayı hedef seçmiştir.

5. Gerçekçidir ve vatan kavramına dayanı ${ }^{61}$.

6. Insan haklarına saygllıdır.

7. Atatürkçü Türk milliyetçiliği çağdaşlaşmayı amaçlar, akılcı ve medeniyetçidir ${ }^{62}$.

8. "Atatürkçü Milliyetçilik" anlayışı sosyal adaletten yanadır ve sınıf kavgasin reddeder ${ }^{63}$.

9. Atatürk'ün Milliyetçilik anlayışı, O'nun Türklük duygusuna ve milletine olan güvenine dayanir ${ }^{64}$.

10. "Atatürkçü Milliyetçilik" anlaylşı "Yurtta Sulh Cihanda Sulh" arzu ve inancını gerçekleştirmeyi hedef alır ${ }^{65}$.

\section{Halkçılık}

Halk, aynı ülkede oturan ve ortak çıkarlarla birbirine bağlı kişilerin tümü, bir ulusu oluşturan insan topluluğu anlamına gelir. Halkçıllk ise, bir ülkede yaşayan bireyler arasında hiçbir hak ayrılığı görmemek, topluluk içinde hiçbir ayrıcalık kabul etmemek, halk adı verilen tek ve eşit bir varlık

59 Sadi Borak, Atatürk’ün Resmi Yayınlara Girmemiș Söylev, Demec, Yazıșma ve Söylesileri, Ankara 1980, s. 226.

${ }^{60}$ Hamza Eroğlu, Atatürk ve Millîyetçilik, Ankara, 1992, s. 83.

${ }^{61}$ Yusuf Sarınay, a.g.e., s. 84-91.

62 Turhan Feyzioğlu, a.g.e., s. 58-91.

63 A.g.e., s. $69-78$.

64 Şerafettin Turan, "Atatürk Milliyetçiliği”, Belleten: Atatürk Özel Sayısı, C. LII, (1981), S. 204, s. 850.

${ }^{65}$ Mustafa Keskin, Atatürk'ün Millet ve Milliyetçilik Anlayıșı, Ankara, 1999, s. 122. 
tanımak görüş ve tutumudur ${ }^{66} .1789$ Fransız İhtilali sürecinde halk, "vatandaş" adını almış ve vatandaşlığın temel nitelikleri; “özgürlük, kardeşlik, eşitlik ve adalet”, olarak adlandırılmıştır ${ }^{67}$.

Atatürkçü halkçılık ilkesi, cumhuriyetçilik ve Milliyetçilik ilkesinin doğal bir sonucu, aynı zamanda diğer ilkelerin de gerekçesidir. Atatürk'ün halkçılığı O’nun demokrasi anlayışı ile eş anlamlıdır. Mustafa Kemal'e göre ${ }^{68}$ : "Demokrasi prensibi, halkçılık: Bu prensibe nazaran, irade ve hâkimiyet, milletin umumuna aittir ve ait olmalıdır. Demokrasi prensibi, hâkimiyeti milliye prensibi şekline inkılâp etmiştir." Millî Mücadele döneminin en etkili düşünce akımı halkçılıktır. Dönemin düşüncelerini felsefi bir biçime dönüştüren ve topluma kabul ettirmekte büyük bir yeteneğe sahip olan Ziya Gökalp'in; "siyasette mesleğimiz Halkçılık, harsta mesleğimiz Türkçülük" diye özetlenebilen ${ }^{69}$ görüşleri, Atatürk'e ve Cumhuriyeti kuranlara esin kaynağı olmuştur. Ziya Gökalp'e göre, "Seçkinlerin çocukken aldıkları eğitimde ulusal kültür yoktu; çünkü okuduklar okullar halk okulu da ulusal okul da değildi. Bundan dolayl, ulusumuzun aydınlarl ulusal kültürden yoksun olarak yetiştiler." Gökalp'e göre, "seçkinlerin uygarlığl vardır, halkta kültür." Bu nedenle, aydınların, halktan kültürel eğitim almak ve halka uygarlığ 1 götürmek için halka doğru gitmeleri gerekir ${ }^{70}$.

Atatürk'ün kültür ve uygarlık anlayışı, Ziya Gökalp'in bu husustaki düşünceleriyle çelişse de, aydınların görevleri hakkında benzer düşünceleri paylaştıkları görülmektedir. Atatürk’e göre, "aydın sınıfin halka telkin edeceği ülküler, halkın ruh ve vicdanından alınmıs olmall." Atatürk, Mart 1923 'de yapmış olduğu konuşmasında bu esası şöyle vurgular ${ }^{71}$ :

"Münevverlerimiz milletimi en mes'ut millet yapayım der. Başka milletler nasıl olmuşsa onu da aynen öyle yapayım der. Lakin düşünmeliyiz ki, böyle bir nazariye hiçbir devirde muvaffak olmuş değildir. Bir millet için saadet olan bir şey diğer millet için felaket olabilir. Aynı sebep ve şerait birini mes'ut ettiği halde diğerini bedbaht edebilir. Onun için bu millete gideceği yolu gösterirken dünyanın her türlü ilminden, keşviyatından, terakkiyatından istifade edelim. Lâkin unutmayalım ki, asıl temeli kendi içimizden çıkarmak mecburiyetindeyiz."

\footnotetext{
${ }^{66}$ Türk Dil Kurumu, Türkçe Sözlük, Ankara, 1974, s. 354-355.

${ }^{67}$ Cahit Tanyol, Atatürk ve Halkçllı, Ankara, 1984, s.68-69.

${ }^{68}$ Afet İnan, Vatandaș İcin Medeni Bilgiler, I. Kitap, İstanbul, 1930, s. 32.

${ }^{69}$ İhsan Güneş, Birinci TBMM’nin Düșünce Yapısı, Ankara, 1997, s.193-195.

${ }^{70}$ Ziya Gökalp, Türkçülüğün Esasları, Hazırlayan: Zeynep Güleç, İstanbul, 2005, s.53-54.

${ }^{71}$ Atatürk'ün Söylev ve Demeçleri, C.II, s.140-141.
} 
Anlaşılacağı üzere, Atatürk'ün halkçılık düşüncesi ve uygulamaları da Türkiye'ye özgü bir karakter taşır. Halkçılık, yurdu ayrıcalık iddialarından koruyan bir ilkedir. Atatürkçülük'te halkçılığın birinci vasfi, demokrasiye bağlı kalmak; ikinci vasfı, halkın genel hakları dışında hiçbir kişiye veya topluluğa ayrıcalık tanımamak; üçüncü vasfi ise sınıf mücadelesini kabul etmemektir. Atatürkçülük'te halkçılık ile demokrasi eş anlamlıdır ${ }^{72}$.

Halkçılık, Atatürk'ün millî egemenlik ve tam bağımsızlık ilkeleriyle birlikte, en çok üzerinde durduğu ilkedir ${ }^{73}$. Atatürk'e göre, bu ilke, özellikle cumhuriyetçilik ve Milliyetçilik ilkelerinin de çıkış noktasını teşkil eder. Atatürk bu hususu sıkça vurgular. Örneğin Temmuz 1920'de yaptığ konuşmada $^{74}$ :

“... Bugünkü mevcudiyetimizin, mahiyet-i asliyesi, milletin temayülatı umumiyesini ispat etmiştir, o da halkçıllktır ve halk hükümetidir. Hükümetlerin halkın eline geçmesidir... İdareyi halka teslim etmek için çalışalım." Mart 1921'de ${ }^{75}$ : “...Siyaseti dâhiliyemizde şiarımız olan halkçılık, yani milleti bizzat kendi mukadderatına hâkim kılmak esası, Teşkilat-ı Esasiye Kanunumuzla tesbit edilmiştir."

Atatürk, sadece Padişah'ın kişisel egemenliğine son vermek için değil, onun yerine halkın halk tarafından yönetilmesi, yani demokrasiye geçilmesi için mücadele vermiştir. Atatürk'ün 24 Nisan'da TBMM'ne sunduğu önerge ve O'nun halkçılık programı, 20 Ocak 1921 tarihinde Meclis'te kabul edilen Teşkilat-1 Esasiye Kanunu'na zemin oluşturmuştur ${ }^{76} .1921$ Anayasası, meşruiyetin kaynağını halkta gören bir öze sahiptir. Bu anlamda halkçılık, kuvvetin, kudretin, hâkimiyetin ve idarenin doğrudan halka verilmesini, yani demokrasiyi ifade eder. Bu anayasa da Cumhuriyet'in ilânına temel teşkil etmiştir. Böylece, millî egemenlik ilkesi, halkçıllk ilkesiyle bütünleştirilerek, devlete demokratik bir nitelik kazandırılmıştır. Özetlersek; Atatürk'ün halkçllık düşüncesi, siyasal rejim ve bir yönetim sistemi olarak hayata geçirilmiştir.

Atatürk'e göre, devlet halk için vardır ve halkın haklarını koruyan bir hukuk devletidir. Çünkü77 ; "Türkiye devleti bir halk devletidir." Halkçıllk ilkesi, bireyin yasalar karşısında eşitliğini ifade eder; herhangi bir fert ya da

\footnotetext{
${ }^{72}$ Genelkurmay Başkanlığı, Atatürkçülük: Atatürkçü Düșünce Sistemi, C.III, Ankara, 1997, s.37-38.

${ }^{73}$ Ergun Özbudun, “Atatürk ve Halkçılık”, Atatürkçü Düșünce, Ankara,1992, s.433.

${ }^{74}$ Atatürk'ün Söylev ve Demeçleri, C. I, s.90.

75 A.g.e., s. 166.

76 İ̀s.en Güneş, a.g.e., s.193-206.

${ }^{77}$ Atatürk'ün Söylev ve Demeçleri, C. I, s.320.
} 
zümreye temel haklar dışında ayrıcalık tanımaz. Atatürk'ün kurduğu ve yönettiği CHP'nin 1935 yılında kabul edilen programında bu husus şöyle vurgulanmıştır ${ }^{78}$ :

“... Kanun karşlsında saltık bir eşitlik kabul eden ve hiçbir ferde, hiçbir kişiye, hiçbir klasa, hiçbir cemaate ayrılık tanımayan yurttaşlarl, halktan ve halkçı kabul ederiz."

"Atatürkçü Halkçılık" anlayışına göre eşitlik, hukuki anlamda bir eşitliği içerir, bireyler dil, din, ırk, sınıf, cins vb ayırıma tabi tutulamazlar, kanun önüne bütün yurttaşlar eşittirler.

"Atatürkçü Halkçılık İlkesinin” en belirgin niteliklerinden birisi de, sınıf çatışmasını reddetmesidir. Atatürk'e göre, Türkiye'de, Batı'da olduğu biçimde, çıkarları birbirleriyle çatışan sınıflar yoktur. Mustafa Kemal'e göre, Türkiye'de, çeşitli meslek sahiplerinin çıkarları birbirlerine bağlı olduğundan ${ }^{79}$ : "Onları sinıflara ayırmak imkânı yoktur ve heyeti umumiyesi halktan ibarettir..." Halkçılık ilkesi, Türkiye halkını, ayrı ayrı sınıflardan oluşmuş değil, kişisel ve sosyal hayat için, iş bölümü bakımından çeşitli meslek gruplarına ayrılmış bir toplum olarak kabul etme anlayışını içeriir ${ }^{80}$. "Atatürkçü Halkçılık", sınıf mücadelesi yerine, sosyal düzen ve dayanışmayı amaç edinir ${ }^{81}$.

"Atatürkçü Halkçılık", devletin halkla, halkın devletle bütünleşmesini sağlayan, halkın refah seviyesini yükseltmeyi esas alan ilkedir. Ülkenin ekonomik kalkınması, halkın tüm olanakları ile iş hayatına katılmasına bağlıdır. Atatürk'e göre ${ }^{82}$ : "Halk dönemi, iktisat dönemi" demektir. Devletin öncelikli görevi ise, halkın güvenliğini ve refahını sağlamaktır. "Çünkü zamanımı tamamen bir iktisat devresinden başka bir şey değildir.”

İktisadi kalkınmanın halka yönelik uygulamaları, halkçılık ilkesinden kaynaklanır ve devletçilik politikasının esasını oluşturur. Halkçılık ilkesine işlerlik kazandırılması ise devletin adaletli bir gelir dağılımını sağlayabilmesine ve tüm bireylerin menfaatlerini dengeli ve uyumlu bir şekilde gözetmesine, modern sosyal devletin gereklerini yerine getirmesine bağlidır ${ }^{83}$.

${ }^{78}$ C.H.P. Dördüncü Büyük Kurultay Görüșmeleri Tutulgası (9-16 May1s 1935), Ankara, 1935 , s.78.

${ }^{79}$ Atatürk'ün Söylev ve Demeçleri, C. II, s.98.

80 Atatürk'ün Söylev ve Demeçleri, C. II, s.112.

81 Ahmet Bekir Palazoğlu, Atatürk İlkeleri, Ankara, 1998, s.4-5.

${ }^{82}$ Atatürk'ün Söylev ve Demeçleri, C. II, s.100.

${ }^{83}$ Ergun Özbudun, a.g.m., s.68. 
Türkiye'deki halkçılık uygulamalarının esasını ise halkın maddi ve manevi ihtiyaçlarının devlet tarafından karşılanmaya çalışılması teşkil etmiştir ${ }^{84}$.

\section{Atatürk’ün halkçılık anlayışının temel nitelikleri şöyle özetlenebilir:}

1.Bütün ulus fertlerini ayrllk kabul etmeksizin ülkenin sahibi sayar.

2.Ulusal egemenliğin ve ulusal iradenin halktan kaynaklandiğını esas aldığından dolayl, demokratiktir.

3.Bireyi yasalar önünde eşit kabul eder.

4.Bireylerin devlet yönetimine eşit olarak katılmalarını sağlar.

5.Devletin vatandaşa, vatandaşın devlete karşı görev ve sorumluluklarını çağdaş ve insani şekilde düzenler.

6. Halkın temel hak ve özgürlüklerini teminat altına alır.

7. Bir sınıfın diğer bir sınıf veya sınıflar üzerinde hâkimiyet kurmasını reddeder.

8.Ulusu iç farklılaşmadan arındırmayl, her türlü ayrışmayı ve toplumsal çatışmayı önlemeyi amaçlar.

\section{Devletçilik}

Devletçilik ilkesi; Atatürk'ün, kısa sürede kalkınmayı gerçekleştirmek amacıyla, 1930 yılından itibaren uyguladığı iktisat politikasıdır. Bu anlamda ekonomik devletçilik, devletin işletmeci olarak da iktisadî yaşama müdahalesini öngören bir anlayıştır. Devletçilik, 1920’li yıllarda Türk özel girişimcilerinin başaramadığı, başaramayacağı; fakat ulusal ekonomi için derhal yapılması gerekli işlerin devlet tarafından yerine getirilmesini içerir.

Türkiye'de; mutedil bir ekonomik sistemin uygulanmasını gerektiren önemli nedenler vardı.

Osmanlı Devleti'nin son yıllarında iktisadî alandaki kalkınma faaliyetleri; 1911-1918 yılları arasında ülkenin devamlı savaş halinde olması nedeniyle kesintiye uğramıştı. 1920'li yıllarda Türkiye ekonomisi, alınan çeşitli önlemlere rağmen, bir türlü istenilen ölçüde geliştirilememişti. Atatürk'ün 1920'de tayin ettiği şu hedefe 1929'da ulaşılamadı ${ }^{85}$.

\footnotetext{
${ }^{84}$ Atatürkçülük: Atatürkçü Düșünce Sistemi, C. III, s.44.

85 TBMM Gizli Celse Zabitları, Cilt: 1, Devre: 1, İçtima: 1, 24 Nisan 1336 (1920) - 21 Şubat 1336 (1921), Ankara, 1980, s.4.
} 
"Hakikatte bütün gayemiz bu hududu millî (Misak-ı Millî) dâhilindeki milletimizin istirahatını, refahını ve bu hududu milli ile muayyen vatanımızın tamamiyetini masun bulundurmaktan ibaretti..."

"Siyasi bă̆ımsızlı̆̆ın, iktisadi bă̆ımsızlıkla korunabileceğine" ${ }^{, 86}$ inanan Atatürk'e göre, devletin ve hükümetin bütün programları iktisat programından çıkarılmalıydı ${ }^{87}$. İktisat programının esaslarını da halkın temsilcileri saptamalıydı. İşte, İzmir İktisat Kongresi, 17 Şubat - 4 Mart 1923 tarihlerinde bu amaçla topland. Kongre sonunda "Misak- Iktisad" " kabul edildi ${ }^{88}$. Tavsiye niteliğinde önemli kararlar alındı: Âşar vergisi kaldırılacak; tarım modernleştirilecek; özellikle hammaddesi yurt içinde bulunan sanayi dalları kurulacak; yer altı servetleri saptanacak ve işletilecek... Türkiye halkı yalnız kendisine güvenecekti ${ }^{89}$.

Türkiye'de 1920'li yılarda; tarıma dayalı sanayileşme desteklendi, Âşar vergisi kaldırıldı, bayındırlık, ulaştırma, bankacılık ve ticaret alanlarında bazı önemli adımlar atıldı. Fakat 1929 y1lı itibariyle ekonomik alanda istenilen düzeyde gelişme sağlanamadı ve halkın geçim vaziyeti iyileştirilemedi $^{90}$. Başka bir anlatımla özel girişimin devlet tarafından desteklenmesi ve bu yöntemle iktisadî kalkınmanın gerçekleşmesi uygulaması başarısızlıkla sonuçlandı. Devletçi iktisat sistemine geçiş nedenleri şöyle özetlenebilirr ${ }^{91}$ :

1. Türkiye'de, ekonomik kuruluşların ana öğesi olan "millî sermayenin" bütün "teşvik ve korumalara rağmen" çok zaylf oluşu;

2. Kuruluşların teknik ve yönetim yeteneğine ve geleneğine sahip olmamasl;

3. Anadolu'da iki - ̈̈ç yıl süren kuraklık;

4. Işs adamlarının kendilerine yabancı gelen alanlarda iş görmekten kaçınmaları;

5. 1929 - 1930 Buhranı'nın meydana getirdiği yıkıcı etkiler;

6. Lozan Anlaşması'nın gümrük resimlerinin artırılmasını engelleyen hükmü 1929'da kalktığından, önceden hazırlanmış olan “Gümrük Tarife

\footnotetext{
${ }^{86}$ Atatürk'ün Söylev ve Demeçleri, С.П, s.107.

87 A.g.e., s. 111

88 A. Gündüz Ökçün, Türkiye İktisat Kongresi: Haberler, Belgeler, Yorumlar, Ankara, 1981, s.387-388.

${ }^{89}$ A.g.e, s.390-437.

${ }^{90}$ Bilsay Kuruş, İktisat Politikasının Resmi Belgeleri, Ankara, 1963, s.I-V.

${ }^{91}$ Necdet Serin, Türkiye'nin Sanayileșmesi, Ankara, 1963, s.17-38; Mustafa Aysan, Atatürk'ün Ekonomi Politikas1, Kırklareli, 1981, s.29-41; Hamza Eroğlu, Türkiye'de Devletçilik, Ankara, 1981, s.81-94; Şevket Süreyya Aydemir, İnkılâp ve Kadro, İstanbul, 1986, s.64.
} 
Kanunu'nun 1 Ekim 1929'da yürürlüğe girmesiyle; “millî endüstrinin korunması imkânın doğması;

7. Özel sermayenin kaçınılmaz bir şekilde kısa dönemli ve karlı yatırım alanlarına kayma ĕgilimi göstermesi;

8. Atatürk'ün Anadolu'daki inceleme gezilerinde tanı olduğu yoksulluk ve sefalet ${ }^{92}$.

Başta Atatürk olmak üzere, Türkiye'yi yönetenleri yeni bir iktisat politikası arayışına sevk eden en önemli olgu; "1929 Dünya Ekonomik Bunalımidir".

1929 yılında, ABD'de patlak veren "Büyük Buhran”, kisa sürede dünyaya yayılmış ve Türkiye'yi de şiddetli bir biçimde etkilemiştir. Türk ekonomisi, iki önemli kanaldan dünya ekonomisindeki bu bunalımdan etkilenmiştir. Bunlardan birincisi dış ticaret ve tarımsal ürün fiyatlarındaki düşüşler, ikincisi de diş ticaret hacmindeki değişikliklerdir. Buhran'ın Türkiye'ye etkisi daha çok ticaret yoluyla olmuştur. Dış ödemeler dengesi açık vermiş, Türk parasının değerinde önemli düşüşler olmuş, dış ticaret hadleri Türkiye aleyhine gelişmiş, iç ticaret hadleri tarımsal ürünler aleyhine bozulmuş, tarımsal alanda özellikle de sanayi ürünlerinin ekim alanlarında daralmalar olmuş, ülke deflâsyona girmiştir ${ }^{93}$.

Lord Kinross'a göre, "Kemalizm"e 1931 yılında yeni bir ilke daha eklenmiştir; bu ilkenin adı " Türkiye Devletçiliğidir". Bu ilke de diğerlerine kenetlenmiş durumdayd ${ }^{94}$ :

"Devletçilik, sömürgeciliğe Halkçılık yoluyla karşı koyuyor; Laiklik Halkçılı̆̆ın sömürülmesini önlüyor, hepsini yabancı saldırılarına karşı koruyan Milliyetçilik de yaşama hızını İnkılâpçılıktan alıyordu".

Başbakan İsmet İnönü, 1 Mart 1928 tarihinde" : "İktisadîyat devleti, devlet de iktisadîyatı tamamlar. Yüksek gayemiz, iktisadî devlet idaresini meydan getirmek için çareler, vasitalar aramaktır." Sözleriyle bu yeni ekonomi politikasının devletçilik olacağını açıklamıştır. İnönü, 30 Ağustos 1930'da, SCF kurucusu Ali Fethi Okyar'ın; hükümetin politikalarını eleştirilerine ise, "biz devletçiyiz" diyerek yeni iktisadî politikayı "devletçilik" olarak adlandırmıştır".

\footnotetext{
${ }^{92}$ Ahmet Hamdi Başar, Atatürk'le Üc Ay ve 1930'dan Sonra Türkiye, Ankara, 1981, s.21.

93 Mehmet Kayıran, "Türk Tarımında Modernleşme Çabaları (1923-1950)", Hacettepe Üniversitesi, Atatürk İlkeleri ve İnkılâp Tarihi Enstitüsü (Yayınlanmamış Doktora Tezi), Ankara, 1995, s.44-63.

${ }^{94}$ Lord Kinross, Atatürk: Bir Milletin Yeniden Doğușu, Çev. Ayhan Tezel, İstanbul, 1972, s.688.

${ }_{95}$ Şevket Süreyya Aydemir, İkinci Adam, C.I, İstanbul, 1984, s,340.

${ }^{96}$ Hâkimiyet-i Millîye, 31 Ağustos 1930.
} 
Ancak, Atatürk'ün ve Cumhuriyet hükümetlerinin devletçilik anlayış ve uygulamalarının sadece 1929-1930'lu y1llara ait şartların bir eseri olarak başlatıldığını ileri sürmek yanıltıcı olur. Çünkü Osmanlı'dan Cumhuriyet'e devredilen önemli kalıplardan biri de çok boyutlu devletçilik fikridir ${ }^{97}$.

Bu konuda uzun bir tarihi geleneğe sahip olan Türkiye'de devletçilik; ülkenin siyasal, sosyal ve kültürel yapısına yabancı olmayan bir kavramdır. Aslında, Cumhuriyet'in ilk yedi- sekiz yılındaki iktisadî politika, yani "özel sektör yaratma çabası" incelendiğinde devletçi yaklaşımı görmek mümkündür. Nitekim Atatürk ilk kez 1 Mart 1922'de, TBMM'nin açış konuşmasında devletin ekonomiye müdahale edeceğini belirtmiş ve devletleştirmeden söz etmiştir ${ }^{98}$ :

“...Siyaset-i iktisadîyemizin mühim gayelerinden biri de menafi- $i$ umumiyeyi doğrudan doğruya alakadar edecek müessesat-ı iktisadîyeyi kudret-i maliye ve fenniyemizin müsaadesi nispetinde devletleştirmedir."

Atatürk'ün devletçilik anlayışı, demokratik ve halkçı bir karakterdedir. Atatürk, İzmir'de 1931'de yaptığ 1 konuşmasında, devletçilik ilkesinin niteliklerini ve amacını formüllendirmiştir ${ }^{99}$ :

“...Firkamızın takip ettiği program, bir istikametten tamamiyla demokratik, halkçı bir program olmakla beraber iktisadî nokta-i nazardan devletçidir. Bu itibarla firkamıza müstenit olan hükümeti cumhuriyenin her nokta-i nazardan vatandaşın hayatiyle, istikbaliyle ve refahlyla alakadar olması tabiidir. Halkımız tab'an devletçidir ki, her türlü ihtiyacı devletten talep etmek için kendisinde bir hak görüyor... Bu istikametten yürüyeceğiz. Ve muvaffak olacağımızdan şüphe yoktur."

Atatürk, devletçiliğin mahiyeti ve sınırlarını da şöyle çizmiştir ${ }^{100}$ :

"Hulâsa, bizim takip ettiğimiz devletçilik, ferdi mesai ve faaliyeti esas tutmakla beraber, mümkün olduğu kadar az zaman içinde milleti refaha ve memleketi mamuriyete eriştirmek için milletin umumi ve yüksek menfaatlerinin icap ettirdiği işlerde bilhassa iktisadî sahada devleti fiilen alakadar etmektedir."

“Atatürkçü Devletçilik" ilkesinin uygulamalarında ${ }^{101}$ :

\footnotetext{
97 Tekin Alp, Kemalizm, İstanbul, 1936, 244-264. Ziya Gökalp’a göre, “... Memleketimizde büyük sanayinin teșekkülü ise, asla fertlerin ve şirketlerin teşebbüsüyle olmaz. " Ziya Gökalp, "İktisadi Mucize", Makaleler, C.VII, Derleyen, Abdülhaluk Çay, Ankara, 1982, s, 164; "İktisada Doğru", a.g.e., s, 34-40.

${ }^{98}$ Atatürk'ün Söylev ve Demeçleri, C.I, s, 226.

99 Atatürk'ün Söylev ve Demeçleri, C.II, s.262.

${ }^{100}$ Afet İnan, Vatandas İçin Medeni Bilgiler, 1. Kitap, 1933, s.61.
} 
“...Ferdiyet inkişafinın mâni karşısında kalmaya başladı̆̆ı nokta, devlet faaliyetinin sınırını teşkil eder. Fakat devlet, bireyin gelişmesi için genel şartları göz önünde bulundurmalıdır... Ve nihayet fertler, bazı büyük müşterek menfaatleri tatmine muktedir olamazlar... Bu izah ettiğimiz manada ve telakkide, devletçilik, bilhassa içtimaî, ahlaki ve millîdir."

Atatürk, herhangi bir iktisadî doktrinin etkisiyle devletçi bir ekonomik modeli benimsememiş, Türkiye'nin ekonomik koşullarını ve dünya ekonomisinin genel durumunu dikkatli bir biçimde inceleyerek bu yolu seçmiştir. Atatürk'ün ifadesiyle ${ }^{102}$ :

“Türkiye 'nin ihtiyaçlarından doğmuş, Türkiye'ye has bir sistemdir."

"Atatürkçü Devletçilik” ilkesi; Türkiye halkını geri kalmışlık ortamından hızla çıkarmayı amaç edinmiştir. Böylece, Türkiye'de; demokratik ve çağdaş bir topluma geçiş için gerekli sosyo-ekonomik bir zemin hazırlanmıştır. İktisadî alandaki devletçilik uygulamalarıyla; Türk halk1, demokratik hak ve özgürlüklerle bağdaşmayan tekelci kapitalist ve kolektivist doktrinlerin olumsuz etkilerinden de korunmuştur. Atatürk döneminde izlenen iktisat politikaları sonucunda, ülke ${ }^{103}$ : "Enflasyondan uzak kalmış, GSMH's1 1938 fiyatlarıyla 1923/24'de 696 milyon TL'den, 1937/38'de 1818 TL'ye, yani 2,6 katına; kişi başına gelir ise 53 TL'den 108 TL'ye (iki katına) çıkmışırı."

Devletin iktisadi hayata işletmeci olarak da katılmasını öngören devletçilik uygulamaları sonucunda, Türkiye ekonomisi yeniden yapılandırılmış; Sümerbank, Etibank, Toprak Mahsülleri Ofisi gibi kuruluşlar oluşturulmuş; Karabük Demir Çelik, Paşabahçe Şişe Cam, Gemlik Suni İpek, İzmit Kâğıt ve Selüloz, Keçiborlu Kükürt vb. pek çok fabrika hizmete açılmış; kibrit, tütün, alkol gibi tekeller örgütlendirilmiş; bankac1lık geliştirilmiş, ülke "demir ağlarla örülmüştür."

\section{Atatürkçü devletçilik ilkesinin temel özellikleri ve hedeflerini şöyle özetleyebiliriz:}

1. Siyasi bağımsızlı̆̆ın temeli olan ekonomik bağımsızlı̆̆ı korumayı esas alan bir savunma ekonomisidir.

2. Ulusal kaynaklara ve göçlere dayanarak kisa zamanda ekonomik kalkınmayı gerçekleştirmek ve kendine yeterli bir ekonomik yapıyı kurmak amaçlanmıştır.

\footnotetext{
${ }^{101}$ Afet İnan, a.g.e., s.56-59.

102 Bilsay Kuruç, Mustafa Kemal Döneminde Ekonomi, Ankara, 1987, s.136.

103 Ömer Celal Sarç, “Atatürk Döneminde Türkiye Ekonomisi ve İktisat Politikaları”, Çağdaș Düșüncenin Ișığında Atatürk, İstanbul, 1983, s.377.
} 
3. Tekelci kapitalizmi ve sosyalizmi reddeden Türkiye'ye özgü bir iktisadi modeldir.

4. Devletin ekonomik alana işletmeci olarak katılımını sağlayan bir anlayışı içerir.

5. Planl kalkınma stratejisini benimseyen bir iktisadi sistemdir.

6. Özel mülkiyet ve girişkenliğe karşı saygılı olan demokratik ve halkçı bir karaktere sahiptir.

7. Devletçilik uygulamaları ile iktisadi alanda entegrasyonun sağlanması ve bölgeler arası gelişmişlik farklılıklarının giderilmesi sağlanmaya çalışılmuştır.

8. Halkın temel ihtiyaçlarını karşılamaya yönelik bir iktisadi politikadır.

\section{Laiklik}

Laik sözcüğü, dilimize Fransızca'dan geçmişse de bu kelime Latince Laicus'dan, o da Grekçe Laikos sıfatından gelmektedir. Grekçe'de laos-halk; Laikos din adamlığı sifat ve yetkisini tanımayan ya da dinle ilgili olmayan, halkla ilgili olan anlamında kullanılmıştır. Buna göre laik kimse, halktan, olan ruhban sınıfina mensup olmayan kimse demektir ${ }^{104}$.

Genel anlamda laiklik, devletin belli bir dini temsil etmekten çıkarılması, din ve devlet ayrılığının sağlanması ve her türlü inanç karşısında tarafsız ve eşit davranmasıdır. Siyasi alanda din ile devletin birbirinden ayrılması ilkesi lâikliği; felsefi alanda toplumun ve bireylerin dinsel kurum ve kuruluşların etkisinden arındırılması ise laikleşme süreci olarak adlandırılabilir.

Türkiye Cumhuriyeti Devleti'nin temel niteliklerinden biri olan laiklik ilkesi ve süreci şöyle tanımlanmıştır ${ }^{105}$ :

"Laiklik din ile dünya, din ile devlet işlerinin ayrılması manasını anlatan bir tabirdir. Bunu dinsizlik manasına almak çok yanlıştır. İnklâbımızın laiklik esaslarını hâkim kılan safhası başlı başına ehemmiyeti haiz bir bahis teşkil eder... Saltanatla hilafetin ayrilmasından başlayarak tedrisatın tevhidi, ser'iye mahkemelerinin kaldırllması, medeni kanun tesisi gibi sahalarda millî hayatımıza nasıl tatbik edildiği... Devlet idaresinde bütün kanunların, nizamların ve usullerin ilim ve fenlerin muasır medeniyete

\footnotetext{
${ }^{104}$ Ethem Ruhi Fığlalı, “İslâm ve Lâiklik”, Atatürk Düșüncesinde Din ve Lâiklik, Ankara, 1999, s. 215

${ }^{105}$ Türk Tarihi Tetkik Cemiyeti, Tarih IV: Türkiye Cumhuriyeti, İstanbul, 1934, s.187.
} 
temin ettiği esas ve şekillere ve dünya ihtiyaçlarına göre yapılmasını ve tatbik edilmesini prensip kabul etmiştir..."

Anlaşılacağı üzere Atatürk'e göre laiklik, sadece din ve devlet işlerinin birbirinden ayrılmasından ibaret bir devlet yönetimi prensibi değil, aynı zamanda bir hayat tarzı, dünya ve toplum sorunlarına 'akılc1 ve bilimci" bir bakış açısıdır. "Bundan dolayıdır ki laiklik, Türkiye'nin çağdaşlaşması temel hedefinden ayrılamaz ve onun zorunlu bir parçasıdır" 106 .

Laiklik: siyaseti, hukuku, eğitimi, ekonomiyi, sanatı vb. toplum ve devlet hayatının gerekli kıldığı bütün alanları dinin, dinsel kuralların etkisinden, tekelinden arındırmaktır. Batı Uygarlığı'nın temelini teşkil eden "hür düşünce, akıl, bilim ve bireyin özgürleştirilmesi" Türkiye'de de sağlanmalıydı. Atatürk, bu değerleri Hıristiyan dünyanın dışına laiklik ilkesi ile taşıd1. Atatürk'e göre ${ }^{107}$ :

“Türkiye Cumhuriyeti'nin resmi dini yoktur. Devlet yönetiminde bütün yasalar, kurallar, bilimin çağdaş medeniliğe sağladiğı esas ve şekillere, dünya ihtiyaçlarına göre yapılır ve uygulanır. Din anlayışı vicdanî olduğundan Cumhuriyet, din fikirlerini devlet ve dünya işlerinden ve siyasetten ayrı tutmayı milletimizin çağdaş ilerleyişinde de başlıca başarı etkeni görür."

Atatürk düşünce ve vicdan özgürlüğünü temel bir hak olarak öngörmüş ve yurttaşların bu hakkına hiç kimsenin karışma yetkisinin olmadığını şöyle vurgulamıştır ${ }^{108}$ :

"Türkiye'de hiçbir kimse fikirlerini zorla başkalarına kabul ettirmeye kalkuşamaz ve böyle bir şeye izin verilemez..."

Atatürk, din özgürlüğünü bir hak olarak görmeyen kişileri ise “bağnaz” olarak tanımlamıştır ${ }^{109}$ :

“...Çeşitli inanışl kimseler, birbirlerine, kin, nefret besliyorlarsa, birbirlerini hor görüyorlarsa ve hatta sadece birbirlerine actyorlarsa, bu gibi kimselerde bağnazsızlık yoktur; bunlar bağnazdırlar."

Atatürk'ün laiklik anlayışı ve uygulamalarında din etkisiz bırakılmamıştır. Osmanlı Devleti'ndeki reform çabalarına din adına dinsel güçlerin karşı koyması, III. Selim'in öldürülmesi, 1909 gericilik eylemi, Millî Mücadele döneminde Padişah-Halife'nin başta Şeyhülislâm olmak üzere dinsel resmi örgütün Bağımsızlık Savaşı'na karşı çıkması gibi olaylar

106 Turhan Feyzioğlu, "Atatürk ve Devlet Hayatı" Atatürk İlkeleri ve İnkılâp Tarihi II, Ankara, 1986, s.78.

${ }^{107}$ Afet İnan, Medeni Bilgiler ve Mustafa Kemal'in El Yazıları, Ankara, 2000, s. 73.

${ }^{108}$ Afet İnan, a.g.e., s. 73.

${ }^{109}$ Ayn1 yer, s. 73. 
ve bunların birikimi ulusal hareketin önderlerini dini değil; dinsel güçleri çağdaşlaşmanın bir engeli olarak görmeye yöneltmiştir. Bu nedenlerle de Türkiye'deki laiklik, dini devletin denetlemesi gerektiği biçiminde algılanmış ve uygulanmıştır ${ }^{110}$. Devlet her türlü taassubu, gerçeğe ve dine aykırı boş inançları sürekli olarak kontrol altında tutarak dini inançlara saygısızlığı da önlemeye çalışmıştır. "Layiklik devrimizin ihtiyaçlarından doğma bir zarurettir. Layik olmayan bir devlette, din hürriyetinin de güvenilir bir teminatı yoktur ${ }^{111}$."

Türkiye'deki Laiklik anlayışı ve uygulamalarını, içinde bulunduğu sosyal ve siyasal koşulları, hâkim ve yaygın bir din olan İslâmiyet'in özellikleri geniş ölçüde etkilemiştir. Bu anlamda Laiklik, katı bir ideoloji halinde ansiklopedi ve kitaplardan alınmış bir anlayış değil, "cevherini, mahiyetini ve sınırlarını Türkiye şartlarının tayin ve tesbit ettiği" bir düşünce sistemidir. Laiklik ilkesinin düşünce sistemi olarak anlamı ise şöyle özetlenebilir ${ }^{122}$ : Laiklik, artık dine, insanların bütün hareketlerini ve toplumların bütün faaliyetlerini yönetici, denetleyici, düzenleyici üstün ve mutlak bir mahiyet tanımama; tersine insanın eşyaları ile olan münasebetlerini bilimsel araştırmaların verilerine göre kurma dileğini benimsemekten ibarettir.

Atatürk dine karşı değildi. Fransız Gazeteci Murice Pernot'ye 29 Ekim 1923 'te "Türkiye'nin din siyaseti hakkında şunları söylemiştir: ${ }^{13}$

"Siyasetimizi dine mugayir olmak şöyle dursun din nokta-i nazarından eksik bile hissediyoruz.

Türk milleti daha dindar olmalıdır, yani bütün sadeliği ile dindar olmalıdır. Dinimize bizzat hakikate nasıl inanıyorsam buna da öyle inanıyorum. Şuûra muhalif, terakkiye mani hiçbir şey ihtiva etmiyor. Halbuki Türkiye'ye istiklâlini veren bu Asya milletinin içinde daha karışı, suni, itikat-ı batıladan ibaret bir din daha vardır. Fakat bu cahiller, bu acizler sırası gelince, tenevvür edeceklerdir. Onlar ziyaya takarrüp edemezlerse, kendilerini mahv ve mahkûm etmişler demektir. Onları kurtaracağız..."

Anlaşılacağ 1 üzere Atatürk; teokratik özelliği kalmamış, sade ve akli bir İslâm'a bağlılı̆̆ını ifade etmekte ve Türk milletinin daha çok dindar olmasını

\footnotetext{
${ }^{110}$ Suna Kili, Atatürk Devrimi: Bir Cağgdașlașma Modeli, Ankara, 1981, s. 268- 269.

${ }^{111}$ Ali Fuat Başgil, Din ve Layiklik, İstanbul, 1962, s.171.

112 Bahri Savc1, "Lâiklik Prensibinin Türkiye Şartları İçinde Mütalâası", Ankara Üniversitesi Siyasal Bilgiler Fakültesi Dergisi, C. XIX, (Haziran 1964), S. 2, s.147.

${ }^{113}$ Atatürk'ün Söylev ve Demeçleri, (1918-1937), C. III, Ankara, 1954, s. 69-70.
} 
istemektedir. Batıl inançları din sanan cahiller ve acizler sırası gelince aydınlanacaklardır. Onlar ışığa yaklaşmazlarsa, onların kendilerini perişan ve mahkûm etmelerine de izin verilmeyecek, milletimiz içindeki bu kişilerde kurtarılacaktır. Atatürk döneminde İslamiyet'le ilgisi olmayan hurafelerden "cahilleri” kurtarmak için zaman geldikçe laiklik alanında pek çok atılım gerçekleştirilmiştir.

Mustafa Kemal, modernleşmeye din adına karşı çıkanların aslında Müslümanları gayrimüslimlere esir - köle yapmak isteyenler olduğunu, bu anlayışın İslamiyet'le bir ilgisinin bulunmadığını Adana'da 16 Mart 1923'te yaptığı bir konuşmasında şöyle vurgulamış ve uyarmışıtır ${ }^{114}$ : emrediyor.

“... Neyi ögrrenmek lâzımsa onu ögrenelim. Bize din de, Allah da bunu

Büyük dinimiz çalışmayanın insanlıkla alâkasının olmadı̆̆ını bildiriyor. Bazı kimseler asri olmayı kâfir olmak sanıyorlar. Asıl küfür onların bu zannidır. Bu yanlış tefsiri yapanların maksadı, Islâmların kâfirlere esir olmasını istemek değil de nedir? Her sarıklıyı hoca sanmayın hoca olmak sarıkla değil dimağladır."

Atatürk'ün Türkiye'de uygulamaya çalıştı̆̆ laiklik ${ }^{115}$, “dinsel duyguları ve inançları çeşitli çıkarlara araç yapmaya engel olmaktır." Böylece vicdanlar huzura kavuşturulmuştur. Dinin sosyal bir gerçek olarak kişilerin vicdanlarında yer alması sağlanmış, özgür düşüncenin önündeki engeller ortadan kaldırılmak istenmiştir. Türkiye şartları ve İslamiyet'in özellikleri doğrultusunda din-devlet, din-toplum ilişkileri düzenlenmiştir. Şükrü Hanioğlu ise Fransa'daki laiklikten oldukça fazla etkilenildiğini ve onu güvenilir addederek uygulanmak istendiğini öne sürmektedir ${ }^{116}$. Diyanet İşleri Başkanlığı kurumunun laik devletin bir kuruluşu olarak Türkiye'de korunması Fransa'daki uygulamalara benzemezliğini kanıtlayan pek çok uygulamadan biridir.

Halkın çoğunluğu Hıristiyan olan ülkelerde ruhban sınıfı mevcut olduğu için devletten ayrı ve bağımsız bir dini örgütlenme vardır. Müslümanlıkta ise böyle bir zümre olmadığı için devlet, toplumun dini ihtiyaçlarını karşılamak için dini hizmetleri yürütenleri "devlet memuru" olarak istihdam etmiştir ${ }^{117}$. Devlet ve toplum laikleştirilmeye çalışılınca da, Avrupa'daki laik devletlerde

${ }^{114}$ Atatürk'ün Söylev ve Demeçleri, C. II, s. 128.

115 İbrahim Olgun, “Türkiye'de Laikliği Gerektiren Nedenler”, Atatürk Konferansları (19751976), C. VIII, Ankara, 1983, s. 70-71 (Ss.69-94)

${ }^{116}$ Şükrü Hanioğlu, Atatürk: An Intellectual Biography, Princeton University Press, 2011, Princeton - Oxford, s. 159.

${ }^{117}$ Özer Ozankaya, Türkiye'de Laiklik: Atatürk Devrimlerinin Temeli, İstanbul, 2000, s. 213. 
görülmeyen; Türkiye’ye özgü bir kurum olan Diyanet İşleri Başkanlığı kurulmuştur. Bununla birlikte, çağdaş dünya'ya ayak uydurmak ancak laiklik ilkesiyle mümkündür. "Bu ilke, Atatürk İnkılâbı'nın temelini oluşturmaktadir ${ }^{118}$."

Daniel Dumoulin'e göre Mustafa Kemal, dini siyasete alet eden hilafetle beraber Türkiye'deki diğer dinlere mensup kurumların da kaldırılmasının gerekli olduğunu, onların da dini yetkilerinin dışına çıktığını şöyle ifade etmiştir ${ }^{19}$ :

"Hilafetle beraber mevcut olan Ortodoks ve Ermeni kiliseleri, patrikhaneleri ve Musevi hahamhanelerinin ortadan kaldırılması lâzımdır. Hilafet ve muhtelif patrikhaneler asırlardan beri ruhani yetkilerinin sinırları dışında çok büyük ayrıcalıklar aldılar. Halkın anlayışına dayanarak bahşedilen hukuk dışı ayrıcalıklar ile cumhuriyet idaresinin uygulanması mümkün değildir...”

Mustafa Kemal, Türkiye'deki hiçbir dinin toplum ve devlet üzerinde herhangi bir bask1 aracı olarak kullanılmamasını istemiştir. “O’nun din konusundaki akılcı ve gerçekçi tutumu, hem dindarları hem de dinle ilgisi olmayanları koruyucu ve rahatlatıcı niteliktedir" ${ }^{120}$. İşte bu nedenle laiklik alanında pek çok uygulama hayata geçirilmiştir ${ }^{121}$.

Atatürk'ün başlıca hedefi, Türk milletini millî bir şuura ulaştırmak ve devleti tam bağımsız, millî ve laik bir hale getirmekti. Türk İnkılâbı ne dine yönelik bir hareketti ne de dini ıslah etmeye çalıştı. Enver Ziya Karal' göre ${ }^{122}$ :

"Inkılâp bize ne mi getirdi? Hür bir irade ile iki kanat. Bu kanatlardan biri düşünce hürriyeti, öbürü de vicdan hürriyetidir. Hür irade düşünce hürriyetine dayanır, vicdan hürriyeti ile de yükselir. Gerçek manada ilmi ve dini gerçekler ancak ve ancak hür iradenin bu iki kanadı ile oluşur..."

Türk İnkılâbı'nın önderi Atatürk'ün deyimiyle ${ }^{123}$ : “Artık Türkiye, din ve şeriat oyunlarına sahne olmaktan çok yüksektir. Bu gibi oyuncular varsa, kendilerine başka taraflarda sahne arasınlar."

118 Ünsal Yavuz, Atatürk: İmparatorluktan Millî Devlete, Ankara, 1990, s. 93.

119 04-05-1924, New York Herald Tribune Muhabirine Demeç, Aktaran: Daniel Dumoulin, Atatürk'ten Düşünceler, Ankara, 2000, s. 59.

${ }^{120}$ Ali Sarıkoyuncu, Atatürk: Din ve Din Adamları, Ankara, 2002, s. 233.

${ }^{121}$ Seçil Akgün, Halifeliğin Kaldırılması ve Laiklik (1924-1928), İstanbul, 2006, s. 215-248.

122 Enver Ziya Karal, "Devrim ve Laiklik", Atatürk ve Devrim: Konferans ve Makaleler 1935-1978), Ankara, 1980, s. 204-205.

${ }^{123}$ Ahmet Bekir Palazoğlu, a.g.e., s. 287. 
Atatürk'ün Türkiye'de uygulamaya çalıştığı laiklik, bir yandan çağdaşlaşma karşıtı bir din sömürücülüğü ideolojisine, diğer yandan onu dışarıdan yürütmek isteyen siyasal güçlere karşı ulusal varlığın ve bağımsızlığın korunması için verilen mücadelenin adıdır. Laiklik, aynı zamanda "kişi olarak vatandaş özgürlüğü ilkesidir ${ }^{124}$."

Türkiye'de Laiklik uygulamaları doğrultusunda:1924'te Halifelik kaldırıldı; "Tevhid-i tedrisat Kanunu' kabul edildi; Osmanlı'dan devralınan "dinin siyasi otorite tarafından denetim altında tutulması geleneğinin", çağdaş bir yorumu olarak, dinsel hizmetleri yürütmek ve düzenlemekle görevli "Diyanet İşleri Başkanlığı", kurumu oluşturuldu ve şeriat mahkemeleri kapatıld1. 1925 yılında tarikatlar yasakland1, tekke, zaviye ve türbeler kapatıldı; 1926'da İsviçre'den alınan "Medeni Kanun" ve İtalya'dan alınan Ceza Kanunu kabul edildi. Aynı yıl " Maarif Teşkilatı", hakkında bir yasa kabul edildi; 1928'de “Türkiye Devleti'nin dini İslâmdır.' hükmü ve TBMM'nin şeriatı uygulamakla görevli olduğuna dair ifade Anayasa'dan çıkarıldı. 1937'de Laiklik ilkesi anayasal bir güvenceye kavuşturuldu. Böylece, dinin maddi hayat ve dünya işlerine karışması önlenerek inançların vicdanlardaki yerini alması sağlandı.

Türk ulusu, yüzylllar boyunca Laiklik ilkesinin devlet ve toplum yönetiminde uygulama alanı bulamamış olması yüzünden pek çok acılar çekmiş, gelişme ve ilerlemesi durmuştur. Bu ilke uygulamaya sokularak Türk toplumu çağdaş bir yapıya kavuşturulmuştur ${ }^{125}$.

Sonuç olarak "Atatürkçü Laiklik" anlayışında din, devlet ve siyasete karıştırılmamış, vicdanlardaki yüksek ve kutsal yerini korumuştur. Laiklik, dinsizlik, din düşmanlığı, dine saygısızlık değildir. Aksine, dinin her türlü çıkar hesaplarından uzak tutulması, politikaya alet edilmemesidir. Laiklik, demokratik yönetimin vazgeçilmez ilkesidir; toplumsal barış ve ülke bütünlüğünün güvencesidir.

\section{Atatürk döneminde uygulanan Laiklik sonucunda;}

1. Devlet yönetimine dini kural ve görü̧sler karıştırılmamış.

2. Dinlerin yerini alacak dogmatik bir sistem, Türkiye halkına kabul ettirilmeye çalışılmamıştır.

3. Toplumda din ve vicdan özgürlüğ̈̈ sağlanarak, din ve mezhepleri ne olursa olsun, yurttaşlara eşit işlem uygulanmıştır.

\footnotetext{
${ }^{124}$ Niyazi Berkes, “Atatürk ve Laikliğin İki Kaynağı”, Atatürk ve Devrimler, İstanbul, 1982, s. 166. (Ss. 159-167)

${ }^{125}$ Bkz.: Türkiye Cumhuriyeti'nin Temel İlkelerinden Lâiklik: Panel, Ankara, 1995.
} 
4. Devletin resmi bir dininin bulunmadiğ felsefesi benimsenerek, eğitim lâik, akılcı ve çă̆daş esaslara göre düzenlenmiştir.

5. Düşünce ve inanç ayrllıklarının düşmanlığa dönüşmesi önlenmiştir.

6. Vatandaşlar, hoşgörülü bir davranışa yöneltilerek ülkenin birlik ve beraberliği sağlanmıştır.

7. Atatürk döneminde, hiçbir zaman Lâiklik adına din düşmanlı̆̆l yapılmamış, halkın dini inançlarını rencide edebilecek bir uygulamaya izin verilmemiştir.

8. Kadın- erkek eşitliği sağlanmıştır.

9. Emperyalist devletlerin Müslüman olmayan Türk yurttaşlarının din̂ิ inançlarını bahane ederek, Türkiye'nin iç işlerine karışmaları önlenmiştir...

\section{VI. İnkılâpçılık (Devrimcilik)}

Atatürk; Türk İnkılâbı'na başlamadan önce Türk toplumuna geri kalmışlığını ve Osmanlı Devleti'nin yok olmak üzere olduğunu gördü. Bunun temel nedenini de Batı'daki ilerleme ve gelişmelere kayıtsız kalma ve takip edememe olarak algılad ${ }^{126}$. Atatürk'e göre, Türk milleti ancak ulusal bağımsızlık ve çağdaşlaşma eylemi ile kurtarabilirdi. Atatürk, bu amaca ulaşabilmek için “İnk1lâpçı1lık'ilkesini benimsedi. Atatürkçü İnkılâpçılık anlayışını en iyi yansıtan O'nun şu uygulamaları ve düşünceleridir ${ }^{127}$ :

1. Yeni ve modern, Türk Devleti'nin kurulması.

2. Din ve mezhep ideolojisinin yerine milliyet ideolojisinin milletçe kabul edilmesi.

3. Batı uygarlığını meydana getiren bilim ve vasıtaya bağlanılması.

4. Yeni Türk Devleti kanun ve örgütlerinin dünya ihtiyaçlanına göre düzenlenmesi.

5. Bilimin hayat için tek yol gösterici olarak kabul edilmesi.

Atatürk'ün "İ̀kılâpçılık” anlayışı, durağanlaşmış, katılaşmış, bir toplum düzeni yerine, yeniliklere açık bir dinamizmi ifade eder. Atatürk, ink1lâbı şöyle tanımlamıştır ${ }^{128}$ :

'Devrim, mevcut kurumlarl zorla değiştirmek demektir. Türk milletini son yüzyıllarda geri bırakmış olan kurumlar yıkılarak yerlerine, milletin en

\footnotetext{
${ }^{126}$ Hamza Eroğlu, Türk İnkılâp Tarihi, Ankara, 1990, s. 443- 446.

${ }^{127}$ Enver Ziya Karal. Atatürk ve Devrim: Konferanslar ve Makaleler, Ankara, 1980, s. 45.

${ }^{128}$ Utkan Kocatürk, Atatürk'ün Fikir ve Düșünceleri, Ankara 1995, s. 203.
} 
yüksek uygar gereklere göre ilerlemesini temin edecek yeni kurumları koymus olmaktır."

Türk İnkılâb1; Türk siyasal ve sosyal hayatındaki bir yenileşme ihtiyacının sonucu ortaya çıkmıştır. Türkiye'de her alanda kısa bir zamanda köklü değişiklikler yapan Mustafa Kemal Atatürk, "gerçek inkılâpçıları", şöyle tarif etmiştir ${ }^{129}$ :

“Hakiki inkılâpçılar onlardır ki, "terakki ve teceddüt inkılâbına sevk etmek istedikleri insanların ruh ve vicdanlarındaki temayükü hakikiye nafuz etmesini bilirler. Bu münasebetle şunu da beyan edeyim ki Türk milletinin son senelerde gösterdiği hârikaların yaptığı siyasi ve içtimaî inkılâpların sahibi hakikisi kendisidir. Sizsiniz. Milletimizde bu istidat ve tekâmül olmasaydl, onu yaratmăga hiçbir kuvvet ve kudret kifayet edemezdi...",

Atatürk'ün “İnkılâpç1lık” anlayışı şu özellikleri içerir: Türk toplumunun yapısına uygundur; durağan değil, dinamik bir anlayıştır; zaman ve mekân sınırları içinde bir atılım olmadığından dolayı tutuculuk ve bağnazlığı reddeder; akıl ve bilimsel verilerin 1şığında sürekli bir gelişme ve değişmeyi hedef alır.

Devrimleri koruma amacı "Atatürkçü İnkılâpçıllk" anlayışının bir özelliğidir. Ancak "değişmeyen tek şeyin değişme yasası", olduğunu bilen ve her şeyin her an ileriye doğru geliştiğine inanan Atatürk için; bu atılımları koruma; ancak geriye dönüşü önlemek amacına yönelik olmalıdır. Atatürk'e göre ${ }^{130}$ : "Inkılâbın hedefini kavramış olanlar daima onu muhafazaya mukdedir olacaklardir."

Atatürk'ün devrimcilik anlayışı 1slahat kavramıyla bağdaşmaz. Islahat, yeniden düzenlemedir, bu düzenlemenin içinde eski ile yeninin, zararlı ile faydalının yan yana yaşatılması söz konusudur, ikilik yaratılmıştır. Atatürk İnkılâbı; sadece yeniyi, faydalıyı kabul etmiş, devam edegelen ikilikleri (medreseler, yeni-eski okullar, eski ve yeni uygulamalar vb.) sona erdirmiştir. Atatürk, gerçekleştirilen inkılâpların amacını şöyle açıklamıştır ${ }^{131}$ :

“...Yaptığımız ve yapmakta olduğumuz inkılâpların gayesi, Türkiye Cumhuriyeti halkın tamamen asrî ve bütün mâna eşkâliyle medeni ve içtimaiye haline îsal etmektir. Inkılâbatımızın umdei asliyesi budur. Bu hakikati kabul edemeyen zihniyetleri tarumar etmek zaruridir. Şimdiye kadar milletin dimağını paslandıran, uyuşturan bu zihniyette bulunanlar olmuştur.

${ }^{129}$ Atatürk'ün Söylev ve Demeçleri, C. II, s. 214.

130 Enver Ziya Karal, Atatürk ve Devrim, s.48.

${ }^{131}$ Atatürk'ün Söylev ve Demeçleri, C. II, s. 214. 
Herhalde zihniyetlerde mevcut hurafeler kâmilen tard olunacaktır. Onlar çıkarılmadıkça dimağa hakikat nurlarını infaz etmek imkânsızdır."

"Altı Atatürk İlkesi"nin sonuncusu olan "Devrimcilik" ilkesi, Türk devlet ve toplum hayatının yapılandırılmasına ve işleyişine temel teşkîl eden ilk beş ilkenin anafikrini teşkil eder. Devrimcilik; dogmaların esiri olmamayı, çağın ve toplumun gerekli gördüğü yenilikleri kabul etmeyi, medeni ve insani bir yaşamı savunmayı ifade eden ilkenin adıdır.

Atatürk'e göre, devrimlerin sona ermesi söz konusu değildir ve bir tek insan ömrüne sı̆̆maz ${ }^{132}$ :

"Yurda hizmet, ink1lâba inan ve Cumhuriyet ülküsüne bağlılık... Türkiye Cumhuriyeti Devleti'ne karşı yapmak zorunda olduğumuz ödevler bitmemiştir ve bitmeyecektir.',

Atatürk'ün "Devrimcilik”' ilkesi bilim ve tekniğin ışığında sürekli bir çağdaşlaşmayı içerir. Zihniyet ve kurumlarda yapılan değişiklikler ile her biri diğerini tamamlayan devrim atılımlarının korunması ve geliştirilmesi ancak "İnkılâpçılık” ilkesine bağlı kalmakla sağlanabilir.

Türk Devrimi'nin Mimarı Atatürk'ün “Türk İnkılâbı”na yön veren “Altı İlke"si dün olduğu gibi bugün de, yarın da çeşitli yorumlara tabi tutulacaktır. $\mathrm{Bu}$ yorumlar, O’nu anlamaya, eserini korumaya, Türk milletini "çağdaş medeniyet seviyesinin üzerine çıkarmaya" yönelik girişimler olmalıdır... Asıl mesele, O’nun manevi mirasçıları kimler olacaktır? Atatürk bu sorunun yanıtını şöyle vermiştir ${ }^{133}$ :

"Ben, mânevi miras olarak hiçbir nass-ı katı (Ayet ya da hadiste - bir iş hakkında kanıt olarak gösterilen söz) hiçbir dogma, hiçbir donmuş ve kalıplaşmış kural bırakmiyorum. Benim manevî mirasım, bilim ve akıldır. Benden sonrakiler, bizim aşmak zorunda olduğumuz çetin ve köklü güçlükler önünde belki amaçlara tamamen eremediğimizi, fakat asla ödün vermediğimizi, akll ve bilimi rehber edindiğimizi onaylayacaklardır. Zaman hızla dönüyor, milletlerin, toplumların bireylerin mutluluk ve mutsuzluk anlayışlar bile değişiyor. Böyle bir dünyada asla değişmeyecek hükümler getirdiğini iddia etmek, aklın ve bilimin gelişimini inkâr etmek olur. Benim Türk milleti için yapmak istediklerim ve başarmaya çalıştıklarım ortadadır. Benden sonra, beni benimsemek isteyenler, bu temel eksen üzerinde akl ve bilimin rehberliğini kabul ederlerse, manevî mirasçılarım olurlar."

\footnotetext{
${ }^{132}$ Ahmet Bekir Palazoğlu, a.g.e., s.319.

${ }^{133}$ Utkan Kocatürk, a.g.e., s. 473.
} 


\section{Sonuç}

Ulusal kimliğin oluşturulmasında ve millet şuurunun pekiştirilmesinde "Tarih Bilimi” önemli bir yere sahiptir. Tarih bilincine sahip olunmadan bugünü anlamak ve geleceğe yönelik öngörülerde bulunmak bireyi de toplumu da yanıltır. İşte bu nedenle; geçmişi anlamaya ve yorumlamaya gereksinim duyulur. Biz bu incelemede; Türk milleti tanımının, ülkenin bölünmez bütünlüğünün, üniter ve millî devlet yapısının tartışmaya açıldığı; “Atatürkçülük”ten sapmaların arttığı bir dönemde ulusal egemenliğe dayalı tam bağımsız yeni bir Türk devleti kuran Mustafa Kemal'in düşüncelerini yeniden değerlendirip yorumlamaya çalıştık...

Birinci Dünya Savaşı sonunda yenilen Osmanlı Devleti, Anlaşma Devletleri tarafindan yok sayılmış; "Türk milleti hem devletsiz hem de ülkesiz bırakılmak istenmiştir." "Devlet-i Ebed-i Müddet" bilinci ile yetişmiş olan Mustafa Kemal, "Misak-1 Milli"nin millet temsilcileri tarafindan kabulünü sağlayarak; Kurtuluş Savaşı'na "millilik ve meşruluk" kazandırmıştır. Mustafa Kemal'in "Ya İstiklal Ya Ölüm” parolası ile başlattığı "Bağımsızlık Savaşı" Türk milletinin zaferiyle sonuçlandırılmıştır.

Türkiye Cumhuriyeti'ni maddi ve manevi alanda dünya'nın en uygar ülkeleri düzeyine yükseltmeyi, milleti en geniş varlık, araç ve kaynaklarına kavuşturmayı; "millî kültürümüzü çağdaş medeniyet seviyesinin üstüne" çıkarmayı amaç edinen "Türk İnkılabı" ve onu sürekli kılmak için Mustafa Kemal'in düşüncelerini yansıtan Altı Ilke; "Atatürkçülük" olarak adlandırılmıștır. 1931'de “C.H.F'nin Programı”na, 1937'de 1924 Anayasası'nın önce 1. Sonra 2. Maddelerinde yer alan "Altı İlke": Cumhuriyetçilik, Milliyetçilik, Halkçılık, Devletçilik, Laiklik ve İnkılâpçılık olarak sıralandırılmıştır. Türkiye Cumhuriyeti'nin 1961 ve 1982 Anayasa'larında da bu ilkeler devletin kuruluş - temel felsefesini oluşturduklarından dolayı yer almışlardır.

Atatürk ilkeleri denilince; Atatürk’ün yazdığı, yazdırdığı, söylev, demeç, söyleşileri ile hayata geçirdiği inkılâpların tümü anlaşılmalıdır.

Atatürkçülük, birbiri ile uyumlu olarak bir araya getirilen ilkelerden oluşan bir bütündür. Altı ilkeden birini ele alıp benimsemek ve diğerlerini yok saymak ya da görmezlikten gelmek "Atatürkçü Düşünce Sistemini" anlamayı ve anlatmayı olanaksız hale getirir. Bu nedenle; "Altı Atatürk İlkesi” bu incelemede bir arada incelenmiştir.

Atatürkçülük: akıl ve bilim tarafından belirlenmiş gerçeklere dayalı bir yaşam felsefesidir; Türkiye Cumhuriyeti'ni sonsuza kadar yaşatma ve yükseltme bilincidir; özgür ve bağımsız bir yurttaş olarak 
yaşamanın garantisidir; insan hak ve özgürlüklerine saygıyı temel alan Türk hümanizmidir; demokratik, laik, sosyal bir hukuk devletinin güvencesidir; Türk milletini devletsiz ve vatansız yapmak isteyen emperyalizme ve sömürgeciliğe karşı geliştirilmiş panzehirdir...

Atatürkçülük, dün olduğu gibi, bugün de yarın da Türk ulusunun pusulası, yol haritası olmayı sürdürecektir. Çünkü Atatürkçülük dinamizmdir, yol göstericisi akıl ve bilimdir. Türk milleti, akıl tarafından belirlenmiş bir etik yaşayış yönünde eğitildiği takdirde; geçmişi daha sağlıklı bir biçimde yorumlama yeteneğini geliştirecek ve bugün ülkemizin yaşadığı konjonktürel sorunları tarihsel birikiminden de yararlanarak daha kısa sürede çözebilecektir.

\section{Kaynakça}

Akgün, Seçil, Halifeliğin Kaldırılması ve Laiklik (1924-1928), İstanbul 2006.

Alp, Tekin, Kemalizm, İstanbul, 1936.

Ana Britannica, Cilt: 6 .

Anadolu Üniversitesi Açıköğretim Fakültesi, Avrupa Tarihi, (Editör: Mehmet Kayıran), Eskişehir, 1991.

Atatürk, Mustafa Kemal, Nutuk (Söylev), C. I - II, Ankara, 1986.

Atatürk'ün Söylev ve Demeçleri (1906 - 1938), C. II, Ankara, 1959.

Atatürk'ün Söylev ve Demeçleri (1918-1937), C. III, Ankara, 1954.

Atatürk'ün Söylev ve Demeçleri (1919-1937), C. I, Ankara, 1961.

Atatürk'ün Söylev ve Demeçleri, C. V, Ankara, 1972.

Ateş, Toktamış, Cumhuriyet, Ankara, 1986.

Aydemir, Şevket Süreyya, İkinci Adam, C.I, İstanbul, 1984.

Aydemir, Şevket Süreyya, İnkılâp ve Kadro, İstanbul, 1986.

Aysan, Mustafa, Atatürk'ün Ekonomi Politikası, Kırklareli, 1981.

Başar, Ahmet Hamdi, Atatürk'le Üç Ay ve 1930'dan Sonra Türkiye, Ankara, 1981.

Başgil, Ali Fuat, Din ve Layiklik, İstanbul, 1962.

Berkes, Niyazi, “Yüz Y1l İçinde Atatürk', Atatürk ve Devrimler, İstanbul, 1982.

Berkes, Niyazi, “Atatürk ve Laikliğin İki Kaynağı”, Atatürk ve Devrimler, İstanbul, 1982.

Borak, Sadi, Atatürk'ün Resmi Yayınlara Girmemiș Söylev, Demeç, Yazıșma ve Söyleșileri, Ankara 1980

C.H.P. Dördüncü Büyük Kurultay Görüșmeleri Tutulgası (9-16 Mayıs 1935), Ankara, 1935.

Cumhuriyet Halk Firkası Programı, Ankara, 1931. 
Çeçen, Anıl, Atatürk ve Cumhuriyet, Ankara, 1981.

Demir, Ömer - Acar, Mustafa, Sosyal Bilimler Sözlüğ̈̈, Ankara, 1997.

Develioğlu, Ferit, Osmanlıca - Türkçe Ansiklopedik Lügat, Ankara, 1993.

Dumoulin, Daniel, Atatürk'ten Düşünceler, Ankara, 2000.

Eroğlu, Hamza, Atatürk ve Milli Egemenlik, Ankara, 1998.

Eroğlu, Hamza, Atatürk ve Milliyetçilik, Ankara, 1992.

Eroğlu, Hamza, Türk İnkılâp Tarihi, Ankara, 1990.

Eroğlu, Hamza, Türkiye'de Devletçilik, Ankara, 1981.

Feyzioğlu, Turhan, “Atatürk ve Devlet Hayatı” Atatürk İlkeleri ve İnkılâp Tarihi II, Ankara, 1986.

Feyzioğlu, Turhan, Atatürk ve Milliyetçilik, Ankara, 1996.

Fiğlalı, Ethem Ruhi, "İslâm ve Lâiklik", Atatürk Düşüncesinde Din ve Lâiklik, Ankara, 1999.

Genelkurmay Başkanlığı, Atatürkçülük: Atatürkçü Düşünce Sistemi, C. III, Ankara, 1997 ,

Gökalp, Ziya, "İktisada Doğru”, Makaleler, C.VII, Derleyen, Abdülhaluk Çay, Ankara, 1982.

Gökalp, Ziya, "İktisadi Mucize", Makaleler, C.VII, Derleyen, Abdülhaluk Çay, Ankara, 1982.

Gökalp, Ziya, Türkçülüğün Esasları, İstanbul, 1955- 2005.

Güneş, İhsan, Birinci TBMM'nin Düsünce Yapısı, Ankara,1997.

Güneş, İhsan, Meşrutiyetten Cumhuriyet'e Türkiye'de Hükümetler: Programları ve Meclisteki Yank1ları (1908-1923), İstanbul, 2012.

Hâkimiyet-i Milliye, 31 Ağustos 1930.

Hanioğlu, Şükrü, Atatürk: An Intellectual Biography, Princeton University Press, 2011, Princeton - Oxford.

İnan, Afet, Vatandaș İçin Medeni Bilgiler, 1. Kitap, İstanbul, 1930.

İnan, Afet, Vatandaş İçin Medeni Bilgiler, 1. Kitap, İstanbul, 1933.

İnan, Afet, Medeni Bilgiler ve Mustafa Kemal Atatürk'ün El Yazıları, Ankara, 1988 -2000 .

Kalpakçıŏlu, Fethi Naci, 100 Soruda Atatürk’ün Temel Görüşleri, İstanbul, 1968.

Kaplan, Mehmet - Enginün, İnci - Kermen, Zeynep vd., "Ahmet Ağaoğlu, Milliyetçilik Cereyanının Esasları”, Atatürk Devri Fikir Hayatı, C. I, Ankara, 1981 .

Karaca, Nuray, "Cumhuriyet'in İnşasında Milliyetçilik", Türk Yurdu, Cilt: 32, (Mart 2012), Say1: 295.

Karal, Enver Ziya, “Atatürk ve Türk Devriminin Özellikleri”, Atatürkçü Düșünce, Ankara, 1992. 
Karal, Enver Ziya, "Devrim ve Laiklik", Atatürk ve Devrim: Konferans ve Makaleler (1935-1978), Ankara, 1980.

Karal, Enver Ziya, Atatürk’ten Düşünceler, İstanbul, 1986.

Kayıran, Mehmet, "Ulusal Egemenliğe Doğru: Erzurum ve Sivas Kongrelerinin Toplanması", Anadolu Üniversitesi Eğitim Fakültesi Dergisi, Cilt 3, (1990), Say1: 1.

Kayıran, Mehmet, "Türk Tarımında Modernleşme Çabaları (1923-1950)", Hacettepe Üniversitesi, Atatürk İlkeleri ve İnk1lâp Tarihi Enstitüsü (Yayınlanmamış Doktora Tezi), Ankara, 1995.

Kayıran, Mehmet, "Atatürkçü Düşünce Sisteminin Oluşmasına Neden Olan Etkenler ve Bu Düşünce Sistemi'nin Geliştirilmesi”, Anadolu Üniversitesi Fen-Edebiyat Fakültesi Dergisi, C. 2 (1990), S.2.

Kayıran, Mehmet, "Atatürk, Demokrasi ve Cumhuriyetçilik", ESOGU Osmangazi Haber, Eskişehir, Kasım 2003.

Kaynar, Reşat - Sakaoğlu, Necdet Atatürk Düşüncesi (Sorular ve Konferanslar), İstanbul, 1999.

Keskin, Mustafa, Atatürk'ün Millet ve Milliyetçilik Anlayıșı, Ankara, 1999.

Kili, Suna - Gözübüyük, A. Şeref, Türk Anayasa Metinleri: Sened-i İttifaktan Günümüze, Ankara, 1985.

Kili, Suna, Atatürk Devrimi: Bir Çağdaşlaşma Modeli, Ankara, 1981.

Kocatürk, Utkan, Atatürk'ün Fikir ve Düşünceleri, Ankara, 1995 - 2005.

Kuruç, Bilsay, Mustafa Kemal Döneminde Ekonomi, Ankara, 1987.

Kuruç, Bilsay, İktisat Politikasının Resmi Belgeleri, Ankara, 1963.

Kutay, Cemal, Kurtulușun ve Cumhuriyet'in Manevi Mimarları, Ankara, 1973.

Lewis, Bernard, Demokrasinin Türkiye Serüveni, Çevirenler: Hamdi Aydoğan Esra Ermert, İstanbul, 2003.

Lord Kinross, Atatürk: Bir Milletin Yeniden Doğușu, Çev. Ayhan Tezel, İstanbul, 1972.

Mumcu, Ahmet, Atatürk İlkeleri ve İnkılâp Tarihi II, Eskişehir, 1994.

Mumcu, Ahmet, Atatürkçülükte Temel İlkeler, İstanbul, 1981.

Olgun, İbrahim, "Türkiye'de Laikliği Gerektiren Nedenler”, Atatürk Konferansları (1975-1976), C. VIII, Ankara, 1983.

Ozankaya, Özer, Türkiye'de Laiklik: Atatürk Devrimlerinin Temeli, İstanbul, 2000.

Öksüz, A. Gündüz, Türkiye İktisat Kongresi: Haberler, Belgeler, Yorumlar, Ankara, 1981.

Özbudun, Ergun, “Atatürk ve Devlet Hayatı”, Atatürk İlkeleri ve İnkılap Tarihi II: Atatürkçülük, Ankara 1986.

Özbudun, Ergun, “Atatürk ve Halkç1l1k”, Atatürkçü Düşünce, Ankara,1992. 
Özerdim, Nihat Sami, Atatürkçünün El Kitabı: Doğumu'nun 100. Y1lında Atatürk'e Armağan, Ankara, 1981.

Öztoprak, İzzet, Atatürk Orman Çiftliğinin Tarihi, Ankara, 2006.

Palazoğlu, Ahmet Bekir, Atatürk İlkeleri, Ankara, 1998.

Safa, Peyami, Türk İnkılâbı'na Bakıșlar, Ankara, 1981.

Sarç, Ömer Celâl, "Atatürk Döneminde Türkiye Ekonomisi ve İktisat Politikaları”, Çağdaș Düşüncenin Ișığında Atatürk, İstanbul, 1983.

Sarıkoyuncu, Ali Atatürk: Din ve Din Adamları, Ankara, 2002.

Sarınay, Yusuf, Atatürk’ün Millet ve Milliyetçilik Anlayıșı, İstanbul, 1996.

Savc1, Bahri, "Lâiklik Prensibinin Türkiye Şartları İçinde Mütalâası", Ankara Üniversitesi Siyasal Bilgiler Fakültesi Dergisi, C. XIX, (Haziran 1964), S. 2.

Seignobos, Charles, Avrupa Milletleri'nin Mukayeseli Tarihi, Çev.: Semih Tiryakioğlu, İstanbul, 1960.

Serin, Necdet, Türkiye'nin Sanayileșmesi, Ankara, 1963.

Tanör, Bülent, Osmanl1 - Türk Anayasal Gelișmeleri, İstanbul, 1992.

Tanyol, Cahit, Atatürk ve Halkçılık, Ankara, 1984.

TBMM Gizli Celse Zabıtları, Cilt1, Devre: 1, İçtima: 1, 24 Nisan 1336 (1920) - 21 Şubat 1336 (1921), TBMM Basımevi, Ankara, 1980.

TBMM Zabit Ceridesi, Devre V, Cilt 16 (5 Şubat 1937).

Turan, Şerafettin, "Atatürk Milliyetçiliği”, Belleten: Atatürk Özel Sayısı, C. LII, (1981), S. 204.

Turan, Şerafettin, Atatürk'ün Düșünce Yapısını Etkileyen Olaylar, Düșünürler, Kitaplar, Ankara, 1982.

Türk Dil Kurumu, Türkçe Sözlük, Ankara, 1974.

Türk Tarihi Tetkik Cemiyeti, Tarih IV: Türkiye Cumhuriyeti, İstanbul, 1934.

Türkiye Cumhuriyeti'nin Temel İlkelerinden Lâiklik: Panel, Ankara, 1995.

Yavuz, Ünsal, Atatürk: İmparatorluktan Milli Devlete, Ankara, 1990.

Yeniçeri, Özcan, "İmparatorluktan Cumhuriyete Türk Milliyetçiliğinin Tarihi Evrimi”, Türk Yurdu, C. 13 (Eylül 2011), S. 289. 